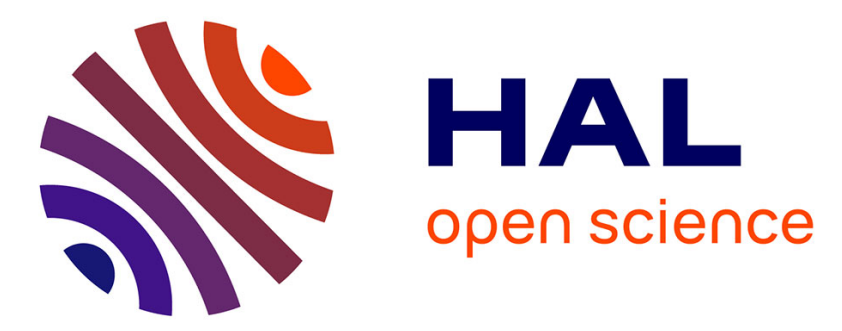

\title{
Mechanistic modeling of turkey growth response to genotype and nutrition
}

\author{
Virginie V. Rivera-Torres, P.R. P. Ferket, Daniel Sauvant
}

\section{To cite this version:}

Virginie V. Rivera-Torres, P.R. P. Ferket, Daniel Sauvant. Mechanistic modeling of turkey growth response to genotype and nutrition. Journal of Animal Science, 2011, 89 (10), pp.3170-3188. 10.2527/jas.2010-3504 . hal-01000206

\section{HAL Id: hal-01000206 https://hal.science/hal-01000206}

Submitted on 29 May 2020

HAL is a multi-disciplinary open access archive for the deposit and dissemination of scientific research documents, whether they are published or not. The documents may come from teaching and research institutions in France or abroad, or from public or private research centers.
L'archive ouverte pluridisciplinaire HAL, est destinée au dépôt et à la diffusion de documents scientifiques de niveau recherche, publiés ou non, émanant des établissements d'enseignement et de recherche français ou étrangers, des laboratoires publics ou privés. 


\section{JOURNAL OF ANIMAL SCIENCE \\ The Premier Journal and Leading Source of New Knowledge and Perspective in Animal Science}

\section{Mechanistic modeling of turkey growth response to genotype and nutrition \\ V. Rivera-Torres, P. R. Ferket and D. Sauvant}

J ANIM SCI 2011, 89:3170-3188.

doi: 10.2527/jas.2010-3504 originally published online May 6, 2011

The online version of this article, along with updated information and services, is located on the World Wide Web at:

http://jas.fass.org/content/89/10/3170

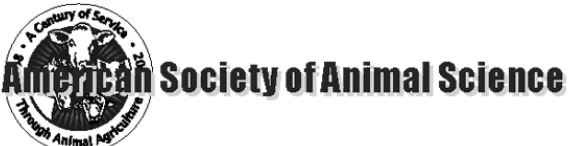

www.asas.org 


\title{
Mechanistic modeling of turkey growth response to genotype and nutrition
}

\author{
V. Rivera-Torres, ${ }^{*} \dagger^{1}$ P. R. Ferket, $\ddagger$ and D. Sauvant $\dagger \S$ \\ *Techna, BP 10, F-44220 Couëron, France; †AgroParisTech, Unité de Formation et de Recherche, \\ Nutrition animale, Qualité des Produits et Bien-être, Département Sciences de la Vie et de la Santé, \\ F-75231 Paris, France; $\ddagger$ Department of Poultry Science, College of Agriculture and Life Sciences, \\ North Carolina State University, Raleigh 27695-7608; and §l'Institut National de la Recherche Agronomique, \\ Unité Mixte de Recherche, Modélisation Systémique Appliquée aux Ruminants, F-75231 Paris, France
}

\begin{abstract}
Along with the fast genetic improvement, nutritional and environmental effects on poultry growth performance have made it necessary to develop growth models that have the flexibility to adapt to different genotypes and growing conditions. A mechanistic simulation model of energy and nutrient utilization in growing turkeys is presented herein. The model consists of simulating the average homeorhetic and homeostatic regulations associated with the utilization of circulating glucose, fatty acid, AA, and acetyl-CoA for protein and lipid retention in carcass, viscera, and feathers in a turkey population. Homeorhesis plays a major role in the control of protein and lipid turnover for the definition of genetic potential and feed intake, whereas homeostasis adjusts growth rate through protein and lipid turnover rates and, therefore, BW gain and feed intake to the growing conditions. Also, homeostasis enables the maintenance of a dynamic balance state during all the growing period through the control of circulating nutrient concentration. The model was developed and calibrated with experimental data that described en-
\end{abstract}

ergy utilization in male and female growing turkeys. Then, the ability of the model to adapt to genotypes and to predict the average response of a turkey population to dietary energy was evaluated. Model calibration showed simulations of energy and nutrient utilization that fitted well with the experimental data because ME was satisfyingly partitioned into heat production and energy retention as protein and lipid, and nutrient intake accurately partitioned BW gain into carcass, viscera, and feathers. The evaluation of the model was also satisfactory because BW gain and feed-to-gain ratio were globally in accordance with the observations in different male and female genotypes, in spite of an overestimation of the feed-to-gain ratio during the first weeks of age. Model evaluation showed that the BW gain and feed intake response of growing turkeys to dietary energy was accurately predicted. The model can therefore be used in different growing conditions as it is capable of simulating the growth of different turkey genotypes fed under changing environmental and nutritional contexts.

Key words: energy, growth, model, nutrient utilization, regulation, turkey

(C)2011 American Society of Animal Science. All rights reserved.

J. Anim. Sci. 2011. 89:3170-3188

doi:10.2527/jas.2010-3504

\section{INTRODUCTION}

The worldwide competitiveness of the meat poultry industry has made it necessary to develop new methods that relate nutrition to production cost and optimize the feeding strategies and the efficiency of nutrient utilization (Baldwin et al., 1980), according to input ingredients, production cost, and market price of poultry meat. Poultry growth models have been developed over the years to better relate BW gain to feed intake. Most

\footnotetext{
${ }^{1}$ Corresponding author: virginie.rivera@gmail.com

Received September 13, 2010.

Accepted May 5, 2011.
}

of these models are based on empirical equations that relate BW or BW gain to time (Buffington et al., 1973; Vitezica et al., 2010) or nutrient intake (Emmans, 1987; King, 2001). A limitation to the use of these models for commercial applications is that empirical equations define nutrient requirements specific to a particular genotype and are not adapted to different environmental conditions (Oviedo-Rondon and Waldroup, 2002). In turkeys, growth model flexibility is essential to account for the effect of sex, genotype, nutrition, and interindividual variability on commercial growth performances.

Metabolic approaches have been suggested as an alternative to simulate growth and nutrient requirements of some genotypes of poultry fed under different nutritional and environmental conditions (Firman, 1994). 
Although no such model seems to be yet available in the poultry literature, several growth models of nutrient metabolism have been developed in other species (Gerrits et al., 1997; Lovatto and Sauvant, 2003; Strathe et al., 2008). We hypothesized that models based on the mechanistic representation of the metabolic regulatory processes are a good means to account for the flexibility in the growth response of commercial turkeys to genotype, nutrition, and environment. The goal of this study was to develop a model capable of simulating the nutritional response of male and female turkey genotypes grown in a controlled environment or in experimental conditions. The study included the following objectives: 1) the development of a teleonomic and mechanistic model of male and female turkey growth; 2 ) the evaluation of the ability of the model to simulate different turkey genotypes; and 3) the evaluation of the ability of the model to predict the average growth response of a turkey population to nutritional inputs. The ultimate goal of this project is to use the model in different genetic, nutritional, and environmental contexts to adapt nutrient recommendations and better promote the competitiveness and sustainability of turkey production.

\section{MATERIALS AND METHODS}

Animal Care and Use committee approval was not obtained for this study because all data used were from previously published studies (i.e., Rivera-Torres et al., 2010b; 2011a,b).

\section{Model Description}

General Structure. Our dynamic mechanistic model simulates the average response of male and female commercial turkeys to genotype and nutrition by simulating the metabolic regulations of energy and nutrient utilization from hatching to slaughter age. The turkey is considered as a teleonomic system, organized and regulated to grow and reproduce for the sustainability of its own species. The model differentiates the regulatory processes from the biological response. Two subsystems constitute the model and continuously interact at different levels of organization (Sauvant, 1992): 1) the decisional system defines the homeorhetic (HR) and homeostatic (HS) regulations that drive growth; and 2) the operational system simulates the composition of the whole turkey body as a response to the decisional system.

The decisional system is associated with HR and HS regulations that control the partitioning of nutrient intake among retention, dissipation, and excretion. The HR regulations define the genetic potential, whereas the HS regulations define the actual growth trajectory as the adaptive response of the genetic potential to growing conditions. The growing conditions refer to the nutritional and the ambient constraints that may result in a growth response that deviates from the genetic potential of the turkey. The nutritional constraints correspond to both the quantity and the nature of nutrient intake. In this model, the ambient constraints are assumed to neither restrict feed intake nor generate any specific response to a stress (i.e., heat stress, or physiological or immunological stress), so the turkey is capable of ingesting the desired amount of feed that allows it to reach its growth trajectory (Emmans, 1987). Feed intake is calculated in the decisional system from the HR and HS regulations that define desired growth. In the operational system, feed intake results in energy and nutrient utilization for the accomplishment of daily $\mathrm{BW}$ gain as a result of protein and lipid retention.

The operational system describes the transformation flows of dietary macronutrients intake into intermediary metabolites for protein and lipid retention (Figure 1). The macronutrients are partitioned into carbohydrates, triglycerides, and AA. The indigestible fraction of these macronutrients is eliminated in the excreta (i.e., feces and urine), whereas the digestible fraction enters the circulating glucose (Gl), AA, and fatty acid (FA) compartments. The circulating Gl compartment represents the major source of energy available in plasma. Each of the circulating AA and FA compartments represents a pivot for $\mathrm{N}$ and lipid utilization, respectively. The utilization of Gl, AA, and FA results in ATP producing and ATP consuming reactions, of which acetyl-CoA (Ay) is an intermediary metabolite. The Ay is preferred over other circulating metabolites because it is a common intermediate in the utilization of circulating Gl, AA, and FA compartments, and it can easily define the ATP production from the different transactions represented in the model. Protein retention corresponds to the difference between the anabolic and the catabolic flows with the circulating AA compartment in carcass, viscera, and feathers (i.e., body component b). Protein retention defines ash and water retention in the body tissues (Emmans, 1989; Eits et al., 2002), and the protein, ash, water, and lipid compartments all constitute the whole body. Similar to protein retention, lipid retention consumes ATP and results from the difference between lipid anabolism and catabolism in carcass and viscera, with the interaction of circulating Gl and FA compartments. The partitioning of protein and lipid retention among carcass, viscera, and feathers enables to account for the differences in the growth rates among these body components (Hurwitz et al., 1991). Finally, the operational system is constituted of 11 body compartments associated with the 4 circulating compartments.

Homeorhetic Regulations. The HR regulations constitute "pull" driving forces that define the genetic potential as a dynamic balance state controlled by both protein and lipid retention in the body compartments of the operational system. Protein and lipid retention result from anabolic and catabolic flows $(\mathrm{g} / \mathrm{d})$, whereas ash and water retention are defined by allometric relations with protein retention (Emmans, 1989; Gous et al., 1999; Eits et al., 2003). The anabolic and catabolic 


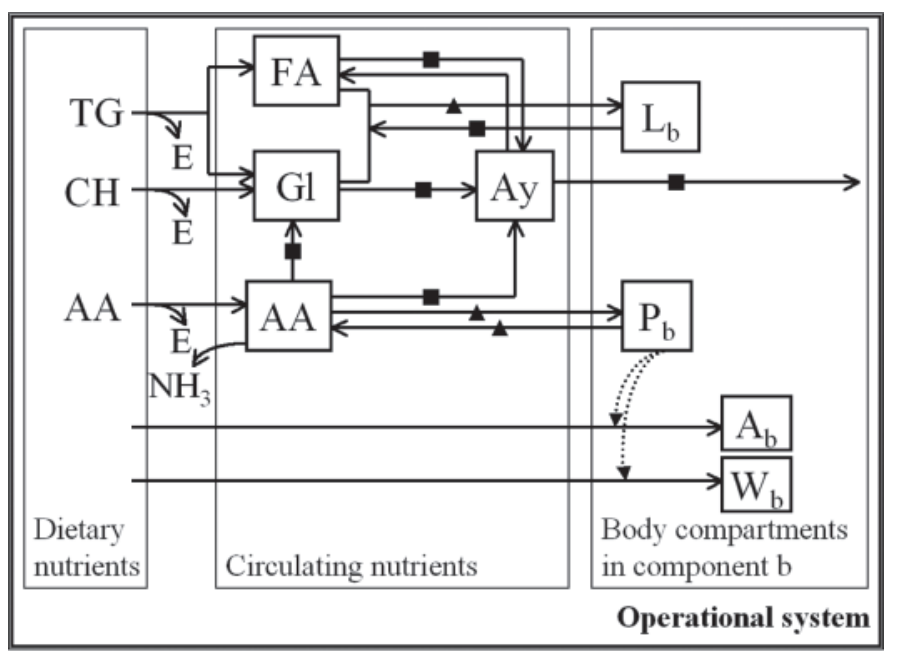

- ATP producing reaction

$\Delta$ ATP consuming reaction

Figure 1. Schematic representation of the operational system of the turkey growth model. The dietary nutrients ingested are triglycerides (TG), AA, and carbohydrates $(\mathrm{CH})$. The indigestible fraction is excreted (E) with $\mathrm{NH}_{3}$, whereas the digestible fraction is an input to the circulating fatty acids (FA), glucose (Gl), AA, and acetyl-CoA (Ay) compartments in the plasma. Protein and lipid metabolism result in the accretion of protein $\left(\mathrm{P}_{\mathrm{b}}\right)$, lipid $\left(\mathrm{L}_{\mathrm{b}}\right)$, ash $\left(\mathrm{A}_{\mathrm{b}}\right)$, and water $\left(\mathrm{W}_{\mathrm{b}}\right)$ in the body compartment of component (b) represented by carcass, viscera, and feathers. No lipid compartment is represented in the feathers. Dotted curved lines represent the effect of $\mathrm{P}_{\mathrm{b}}$ on the inflows to $\mathrm{A}_{\mathrm{i}}$ and $\mathrm{W}_{\mathrm{i}}$.

flows of protein and lipid are controlled by fractional synthesis and degradation rates (FSR and FDR, respectively; $\%$ per day). The daily quantity of protein or lipid retained $\left(\mathrm{R}_{\mathrm{Mb}}, \mathrm{g} / \mathrm{d}\right)$ is defined as a function of the mass of protein or lipid in the body component $\mathrm{b}\left(\mathrm{M}_{\mathrm{b}}\right.$, g) at time t:

$$
\mathrm{R}_{\mathrm{Mb}}(\mathrm{t})=\left[\mathrm{FSR}_{\mathrm{Mb}}(\mathrm{t})-\mathrm{FDR}_{\mathrm{Mb}}(\mathrm{t})\right] \mathrm{M}_{\mathrm{b}}(\mathrm{t})
$$

The FSR and FDR were shown to decrease in the muscle of broilers (Figure 2) and turkeys (Kang et al., 1985a), and in the adipose tissue of broilers during growth (Lemarchal et al., 1988; Foglia et al., 1994). To account for the effect of age on these fractional turnover rates, both the FSR and FDR are defined by a declining exponential function of age (Danfaer, 1991; Lovatto and Sauvant, 2003):

$$
\begin{aligned}
& \operatorname{FSR}_{\mathrm{Mb}}(\mathrm{t})=\mathrm{k}_{\mathrm{s}}+\mathrm{A}_{\mathrm{iMb}} \exp \left(-\mathrm{A}_{\mathrm{eMb}} \mathrm{t}\right) ; \\
& \operatorname{FDR}_{\mathrm{Mb}}(\mathrm{t})=\mathrm{k}_{\mathrm{s}}+\mathrm{C}_{\mathrm{iMb}} \exp \left(-\mathrm{C}_{\mathrm{eMb}} \mathrm{t}\right),
\end{aligned}
$$

where the $\mathrm{k}_{\mathrm{s}}, \mathrm{A}_{\mathrm{iMb}}, \mathrm{C}_{\mathrm{iMb}}, \mathrm{A}_{\mathrm{eMb}}$, and $\mathrm{C}_{\mathrm{eMb}}$ parameters constitute inputs to the model. At the adult state (i.e., zero retention), both the FSR and FDR reach the common decreased value $\mathrm{k}_{\mathrm{s}}$. The $\mathrm{A}_{\mathrm{iMb}}$ (or $\mathrm{C}_{\mathrm{iMb}}, \%$ per day) corresponds to the difference between the initial FSR (or FDR) and $\mathrm{k}_{\mathrm{s}}$. The $\mathrm{A}_{\mathrm{eMb}}$ (or $\mathrm{C}_{\mathrm{eMb}}, \%$ per day) refers to the rate of change of $\mathrm{M}_{\mathrm{b}}$. Differentiating the FSR and FDR of carcass and viscera protein enables distinguishing the retention rates in these 2 body compo- nents during growth (Hurwitz et al., 1991). The FSR and FDR of carcass protein are assumed to be less than that in the viscera (Lovatto and Sauvant, 2003). The FSR and FDR of lipid are assumed similar between carcass and viscera because little information is available on the change in lipid turnover with age and on the partitioning of adipose tissue between carcass and viscera. In feathers, protein retention only depends on its FSR because protein retention in feathers refers to an irreversible exportation from the AA pool (i.e., FDR equals zero).

Homeostatic Regulations. Depending on nutrition and management, protein and lipid retention, and thus daily BW gain, may deviate from the BW gain of the genetic potential. To control such deviations, HS regulations interact with HR regulations as "push" driving forces that limit the difference between the actual growth and the balance state (i.e., defined by the HR regulations) and the flows of nutrients among the compartments of the operational system.

The deviation of the growth rate from the balance state is defined by interday HS regulations. These regulations control the growth rate during the whole life of the individual by adapting the fractional turnover rates of protein and lipid to the growing conditions. Results from the literature demonstrated that nutritional levels (Tesseraud et al., 1992, 2001) and dietary macronutrient composition (Collin et al., 2003) may affect the FSR and FDR of protein and lipid in carcass. Also, lipid turnover changes with nutrition, depending on the amount of ME available in excess and depending on the physiological state, as demonstrated by Baldwin et al. (1980) in dairy cows. Thus, we assume 6 parameters related to the interday HS regulations may change according to growing conditions. These parameters refer to the FSR and FDR of protein in carcass (i.e., $\mathrm{Ai}_{\mathrm{Pc}}$,

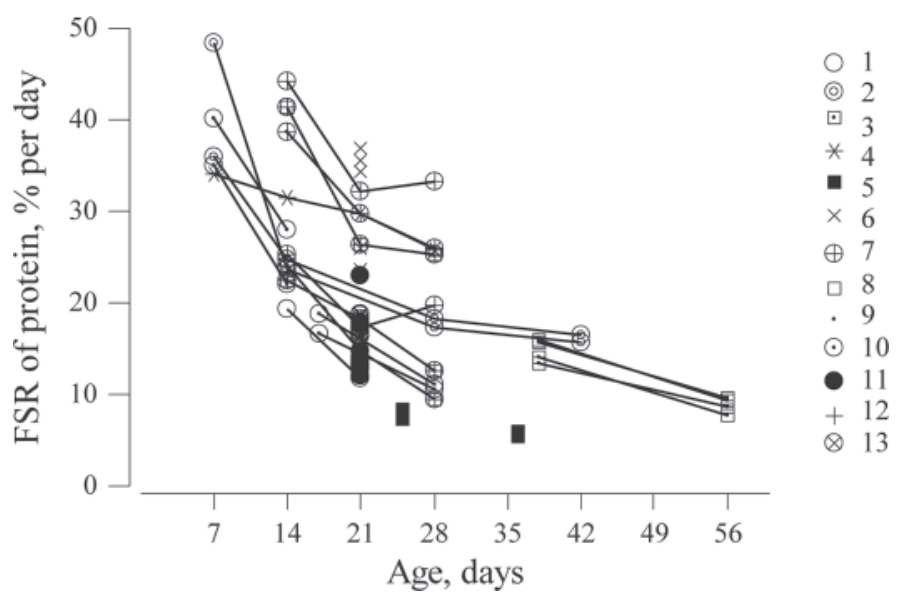

Figure 2. Fractional synthesis rate (FSR) of protein in the broiler with age. References mentioned in the legend are $1=$ Jones et al. (1986), 2 = Kang et al. (1985b), 3 = Morgan et al. (1989), $4=$ Muramatsu and Okumura (1985), 5 = Pym et al. (2004), $6=$ Tesseraud et al. (1992), $7=$ Tesseraud et al. (1996a), $8=$ Tesseraud et al. (1996b), $9=$ Tesseraud et al. (1996c), $10=$ Tesseraud et al. (2000), $11=$ Tesseraud et al. (2001), $12=$ Tomas et al. (1991), and $13=$ UrdanetaRincon and Leeson (2004). 
$\mathrm{Ae}_{\mathrm{Pc}}, \mathrm{Ci}_{\mathrm{Pc}}$, and $\mathrm{Ce}_{\mathrm{Pc}}$ ) and to the FSR of lipid (i.e., $\mathrm{Ai}_{\mathrm{L}}$, and $\mathrm{Ae}_{\mathrm{L}}$ ). The fractional turnover rate of viscera protein is not affected by nutrition because changes in daily BW gain are assumed to be primarily due to changes in carcass gain (Veldkamp et al., 2005; Aimiuwu and Lilburn, 2008). Also, the FDR of lipid is not affected by the interday HS regulations because it is independent of age and its value is small relative to the other fractional turnover rates (i.e., $1 \%$ per day). Although the water-to-protein ratio may be affected by nutrition in broilers (contrary to the ash-to-protein ratio; Eits et al., 2002), the interday HS regulations are assumed to have no effect on the allometric relation of water (and ash) with protein. As a consequence, the interday HS regulations are only due to changes in protein and lipid turnover.

In addition to the interday HS regulations, intraday HS regulations simulate the short-term adaptation of the flows of circulating nutrients to the amount and the nature of the ingredients ingested during the day. The intraday HS regulations generate a buffer for the partitioning of the circulating nutrients among the different compartments because they depend on the instantaneous concentration (i.e., the integration step is the minute) of the circulating nutrients (Gill et al., 1989). The intraday HS regulations are represented by exponential laws of response that depend on both the HR and the interday HS regulations, and on the relative difference between the concentration of the circulating nutrient $\mathrm{i}$ (in $\mathrm{g} / \mathrm{L}$ ) at time $\mathrm{t}\left[\mathrm{C}_{\mathrm{i}}(\mathrm{t})\right]$ and the balance concentration of this circulating nutrient $\left(\mathrm{C}_{0 \mathrm{i}}\right)$, defined as $\Delta \mathrm{C}_{\mathrm{i}}(\mathrm{t})$ (Lovatto and Sauvant, 2003). The flow resulting from the transformation of the circulating compartment $\mathrm{X}$ into $\mathrm{Y}$ is expressed in grams of $\mathrm{Z}$ (or in moles of $\mathrm{Z}$ when mentioned):

$$
\begin{gathered}
\mathrm{F}_{\mathrm{X}, \mathrm{Y} / \mathrm{Z}}(\mathrm{t})=\mathrm{f}_{\mathrm{X}, \mathrm{Y} / \mathrm{Z}}(\mathrm{t}) \exp \left\{\mathrm{Ve}\left[\Delta \mathrm{C}_{\mathrm{i}}(\mathrm{t})\right]\right\} \text {, where } \\
\Delta \mathrm{C}_{\mathrm{i}}(\mathrm{t})=\left\{\left[\mathrm{C}_{\mathrm{i}}(\mathrm{t})-\mathrm{C}_{0 \mathrm{i}}\right] / \mathrm{C}_{0 \mathrm{i}}\right\} .
\end{gathered}
$$

The $f_{X, Y / Z}(t)$ refers to the balance state defined by the $\mathrm{HR}$ and the interday HS regulations discussed before. The $F_{X, Y / Z}(t)$ flow equals $f_{X, Y / Z}(t)$ when $\Delta C_{i}(t)$ equals zero. Similar to a previous version of the model (Rivera-Torres et al., 2010a), the circulating nutrient i creates a return force for $\mathrm{X}$ when $\Delta \mathrm{C}_{\mathrm{i}}(\mathrm{t})$ differs from zero and ensures a fairly constant concentration of nutrient $\mathrm{i}$ by increasing or decreasing $\mathrm{F}_{\mathrm{X}, \mathrm{Y} / \mathrm{Z}}(\mathrm{t})$. Positive intraday HS regulations correspond to positive exponential values $(\mathrm{Ve})$ and result in increasing $\mathrm{F}_{\mathrm{X}, \mathrm{Y} / \mathrm{Z}}(\mathrm{t})$ when $\Delta \mathrm{C}_{\mathrm{i}}(\mathrm{t})$ is greater than zero. On the contrary, negative intraday $\mathrm{HS}$ regulations refer to negative Ve values and induce a decrease in the $\mathrm{F}_{\mathrm{X}, \mathrm{Y} / \mathrm{Z}}(\mathrm{t})$ when $\Delta \mathrm{C}_{\mathrm{i}}(\mathrm{t})$ is greater than zero. Thus, the intraday HS regulations enable the maintenance of a state close to that defined by the HR and interday HS regulations.

Feed Intake. Feed intake results in the transformation of the digestible macronutrients into circulating
Gl, AA, FA, or Ay compartments, which can be further used for protein and lipid retention in the body tissues. Feed intake is due to the HR and interday HS regulations that define the desired growth of each day. Because no nutrient is assumed to be limiting in the diet, feed intake regulation depends on dietary $\mathrm{ME}$ (Emmans, 1987). Feed intake is therefore calculated as the ME intake to dietary ME ratio. The ME intake $[\mathrm{MEI}(\mathrm{t})$, in $\mathrm{kJ} / \mathrm{d}]$ is driven by the HR and interday HS regulations and is defined as the sum of maintenance energy expenditure $\left(\mathbf{M E}_{\mathbf{m}}\right)$ and the energy used for desired protein and lipid retention at time $\mathrm{t}$ (REP and REL, respectively), with $k_{p}$ and $k_{f}$ the energy efficiencies for REP and REL, respectively:

$$
\operatorname{MEI}(\mathrm{t})=\mathrm{ME}_{\mathrm{m}}(\mathrm{t})+1 / \mathrm{k}_{\mathrm{p}} \operatorname{REP}(\mathrm{t})+1 / \mathrm{k}_{\mathrm{f}} \operatorname{REL}(\mathrm{t}) .
$$

The $\mathrm{ME}_{\mathrm{m}}$ is commonly expressed per metabolic BW unit (usually per kilogram $\mathrm{BW}^{0.75}$ or per kilogram $\mathrm{BW}^{2 / 3}$ per day). In this study, the $\mathrm{ME}_{\mathrm{m}}$ per metabolic $\mathrm{BW}$ is a linear function of $\mathrm{BW}$ (with $\mathrm{a}_{\mathrm{MEm}}$ and $\mathrm{d}_{\mathrm{MEm}}$ being, respectively, the intercept and the slope) and depends on sex (Rivera-Torres et al., 2011a):

$$
\mathrm{ME}_{\mathrm{m}}(\mathrm{t})=\left[\mathrm{a}_{\mathrm{MEm}}+\mathrm{d}_{\mathrm{MEm}} \mathrm{BW}(\mathrm{t})\right] \mathrm{BW}(\mathrm{t})^{0.75} .
$$

The macronutrient inputs are determined from feed intake and from the dietary $\mathrm{CP}$, crude fat, and $\mathrm{ME}$ content. Ingested CP and crude fat are associated with AA and triglycerides, respectively, whereas starch, soluble sugars, and soluble fibers intake are assimilated to carbohydrates. The truly digestible fraction of the ingested macronutrients is absorbed by the gut and enters the circulating AA, FA, and Gl compartments. All the $\mathrm{N}$ is provided by the digestible $\mathrm{CP}$ fraction, which is degraded into free AA that constitute inputs to the circulating AA compartment. The triglycerides are degraded into 3 FA and 0.5 Gl. Fatty acids and Gl constitute inputs to the circulating FA and Gl compartments, respectively. The FA are defined as oleic acid equivalents because oleic acid is assumed to be the most concentrated FA in the adipose tissue of poultry, as demonstrated in lean and fat lines of broilers by Lemarchal et al. (1988). Along with the Gl that is formed by degradation of triglycerides, the carbohydrates are ingested as Gl equivalents to enter the circulating Gl compartment. The remaining fraction of ME provided by the diet corresponds to the carbohydrates and is calculated from the energy content of Gl and from the difference between ME intake and the energy content in the digestible $\mathrm{CP}$ and crude fat intake. Consequently, the macronutrient inputs, and thus feed intake, depend on $\mathrm{ME}$ intake and drive $\mathrm{BW}$ gain composition as related to protein and lipid turnover.

A A Utilization. The AA circulating compartment is a pivot for protein retention. The inputs to the AA circulating compartment are the digestible AA and the AA resulting from protein catabolism in carcass and 
viscera. The dietary AA profile corresponds to the ideal protein ratio (Firman and Boling, 1998). The outputs to the AA circulating compartment are the anabolic flows of protein in carcass, viscera, and feathers; the basal ileal AA endogenous losses (IEAA); and the oxidative deamination (i.e., transamination).

Amino acid digestibility depends on the IEAA losses, which correspond to the excretion of protein from mucus, enzyme, and epithelium. To correct AA (or CP) digestibility from these losses, standardized ileal digestibility (SID) values are used. The average SID of AA is determined from the feed ingredient composition and from the $\mathrm{CP}$ content in the feed ingredients (Sauvant et al., 2004). Defining a SID has the advantage over the apparent digestibility in that it accounts for the effect of DM intake on the IEAA (Adedokun et al., 2007a). Although the IEAA losses may vary with $\mathrm{CP}$ and age, particularly during the first week of age (Adedokun et al., 2007b), the IEAA losses were defined as a constant function of DMI.

Oxidative deamination is due to inevitable oxidation losses and to the transformation of the excess of AA into a carbon chain for ATP production, and an amine group for further synthesis of essential AA or rejection as ammonia (or uric acid). The excess of AA corresponds to the difference between digestible CP intake, IEAA losses, and minimal AA oxidation. The carbon chain that is liberated after oxidative deamination, results in either Ay or Gl formation by intraday HS regulations. The oxidative deamination $[\operatorname{AAd}(\mathrm{t})$, in $\mathrm{g} / \mathrm{d}]$ is positively related to $\Delta \mathrm{C}_{\mathrm{AA}}(\mathrm{t})$ :

$$
\operatorname{AAd}(\mathrm{t})=\mathrm{k}_{\text {ox }} \operatorname{AA}(\mathrm{t}) \exp \left\{\operatorname{Ve}_{\mathrm{AAox}}\left[\Delta \mathrm{C}_{\mathrm{AA}}(\mathrm{t})\right]\right\} .
$$

The $\mathrm{k}_{\mathrm{ox}}$ value refers to the minimal AA oxidation rate (in \%), and $\mathrm{AA}(\mathrm{t})$ corresponds to the mass (in $\mathrm{g}$ ) of the circulating AA compartment at time t. A deficiency in the concentration of circulating Gl results in increasing inputs of Gl from the circulating AA compartment, whereas the reverse is true in case of an increased concentration in the $\mathrm{Gl}$ compartment:

$$
\mathrm{F}_{\mathrm{AA}, \mathrm{Gl} / \mathrm{AA}}(\mathrm{t})=\operatorname{AAd}(\mathrm{t}) \exp \left\{-\mathrm{Ve}_{\mathrm{Gl}}\left[\Delta \mathrm{C}_{\mathrm{Gl}}(\mathrm{t})\right]\right\} .
$$

Based on the determination of the rate of oxidative deamination and of the quantity of AA transformed into Gl equivalents, the quantity of AA that results in Ay formation $\left(\mathrm{F}_{\mathrm{AA}, \mathrm{Ay} / \mathrm{AA}}\right)$ is calculated:

$$
\mathrm{F}_{\mathrm{AA}, \mathrm{Ay} / \mathrm{AA}}(\mathrm{t})=\operatorname{AAd}(\mathrm{t})-\mathrm{F}_{\mathrm{AA}, \mathrm{Gl} / \mathrm{AA}} .
$$

Gl and FA Utilization. Glucose and FA utilization enable lipid retention. The inputs to the circulating Gl compartment are the macronutrients absorbed as Gl equivalents, Gl originating from the catabolic flow of lipid into Gl and FA, and oxidative deamination flow of AA that are transformed into Gl equivalents. The outputs to the circulating Gl compartment are the Gl that enters the lipid compartments, and Gl oxidation flow into $\mathrm{Ay}\left(\mathrm{F}_{\mathrm{Gl}, \mathrm{Ay} / \mathrm{Gl}}\right)$. Glucose oxidation depends on the intraday $\mathrm{HS}$ regulations defined by $\Delta \mathrm{C}_{\mathrm{Gl}}(\mathrm{t})$. Increasing $\mathrm{Gl}$ oxidation into Ay results from increasing circulating $\mathrm{Gl}$ concentration (i.e., $\mathrm{Ve}_{\mathrm{Glox}}$ is greater than zero):

$$
\mathrm{F}_{\mathrm{Gl}, \mathrm{Ay} / \mathrm{Gl}}(\mathrm{t})=\mathrm{k}_{\mathrm{ox}} \mathrm{Gl}(\mathrm{t}) \exp \left\{\mathrm{Ve}_{\mathrm{Glox}}\left[\Delta \mathrm{C}_{\mathrm{Gl}}(\mathrm{t})\right]\right\} \text {. }
$$

The inputs to the FA circulating compartment are the ingested FA originating from triglycerides, the de novo lipogenesis of FA from Ay $\left(\mathrm{F}_{\mathrm{Ay}, \mathrm{FA} / \mathrm{FA}}\right)$, and the FA formed by the degradation of lipid in carcass and viscera. Glucose is at the origin of the intraday HS regulations of the flows related to Ay compartment because FA synthesis is assumed to be primarily due to increased concentrations of circulating Gl:

$$
\mathrm{F}_{\mathrm{Ay}, \mathrm{FA} / \mathrm{FA}}(\mathrm{t})=\mathrm{k}_{\mathrm{ox}} \mathrm{FA}(\mathrm{t}) \exp \left\{\mathrm{Ve}_{\mathrm{Gl}}\left[\Delta \mathrm{C}_{\mathrm{Gl}}(\mathrm{t})\right]\right\}
$$

The outputs to the circulating FA compartment are represented by the anabolic flows of lipid in body component $\mathrm{b}$ and by the oxidation flow of FA into Ay $\left(\mathrm{F}_{\mathrm{FA}, \mathrm{Ay} / \mathrm{FA}}\right)$. The $\mathrm{F}_{\mathrm{FA}, \mathrm{Ay} / \mathrm{FA}}$ increases with increasing $\mathrm{FA}$ mass and circulating FA concentration:

$$
\mathrm{F}_{\mathrm{FA}, \mathrm{Ay} / \mathrm{FA}}(\mathrm{t})=\mathrm{k}_{\mathrm{ox}} \mathrm{FA}(\mathrm{t}) \exp \left\{\mathrm{Ve}_{\mathrm{FAox}}\left[\Delta \mathrm{C}_{\mathrm{FA}}(\mathrm{t})\right]\right\} .
$$

Thus, the circulating FA concentration is at the origin of FA oxidation, whereas the circulating Gl concentration regulates both Gl oxidation into Ay and de novo lipogenesis.

Energy Utilization. Metabolizable energy utilization corresponds to the partitioning of ME intake between heat production (HP) and energy retention as protein and lipid $(\mathrm{kJ} / \mathrm{d})$. The ME intake is determined by multiplication of the feed intake and the dietary $\mathrm{ME}$ value. Heat production refers to the ATP used during the endogenous reactions (i.e., ATP consuming reactions; Figure 1) and is calculated as the difference between ME intake and energy retention. Heat production is expected to equal the amount of energy produced during the exogenous reactions (i.e., ATP producing reactions; Figure 1), resulting in a zero energy balance.

The exogenous reactions are simulated mechanistically. They correspond to the oxidation of AA, Gl, and FA into $\mathrm{Ay}$, to the Ay oxidation into $\mathrm{CO}_{2}$, and to the lipid catabolism into FA. The oxidation of $\mathrm{Gl}$ and AA into Ay $\left(\mathbf{O X}_{\mathrm{Gl}}\right.$ and $\mathbf{O} \mathbf{X}_{\mathbf{A A}}$, respectively) is determined from the energy costs (i.e., as ATP equivalents) associated with the transformation of circulating Gl and AA into Ay, respectively. The $\mathbf{O X}_{\mathbf{F A}}$ corresponds to the sum of the energy produced during FA oxidation into Ay and during lipid catabolism into FA and Gl. Finally, the $\mathrm{OX}_{\mathrm{Ay}}$ is determined by difference between total $\mathrm{HP}$ and the sum of $\mathrm{OX}_{\mathrm{Gl}}, \mathrm{OX}_{\mathrm{AA}}$, and $\mathrm{OX}_{\mathrm{FA}}$ to result in a zero energy balance between the endogenous and the exogenous reactions. 


\section{Model Development}

Implementation. The model was developed with a software (Modelmaker version 3.0, Cherwell Scientific Publishing Inc., Palo Alto, CA). The model outputs were calculated on a daily basis using the Runge-Kutta method with a fixed integration step of $1 \mathrm{~min}(1,440 \mathrm{in}$ tegration steps per day), which enabled accounting for the intraday HS regulations. Model integration started at hatching $(t=0)$. The mathematical statement of the model is presented in Table A1.

Parameters and Initial Values. The parameters were differentiated between user-defined, fitted, and constant parameters (Table 1). The user-defined parameters corresponded to the parameters that were adapted to every simulation. They referred to the dietary DM, ME, crude fat, and CP contents, and to the ages at feed transition. All the parameter values were first defined during calibration. The defined and constant parameters were not changed during evaluation, whereas some fitted parameters were adjusted during model evaluation. The constant parameters were taken from the literature and were assumed not to change between individuals of a same sex. They corresponded to stoichiometry parameters, digestibility values, the ATP produced during exogenous reactions, and the parameters related to the definition of ME intake (Table 2).

The initial values (i.e., day of hatching) of the composition in protein, lipid, ash, and water were taken from the serial slaughter analyses performed at $7 \mathrm{~d}$ of age (Rivera-Torres et al., 2011b). The initial values of the circulating compartments were determined from the balance concentration of the circulating nutrients and from the plasma volume of the turkey at hatching, assuming an initial BW of $60 \mathrm{~g}$ in both males and females.

\section{Model Calibration}

The calibration was performed to determine the values of the fitted parameters to validate the adequacy of the structure and functions of the model with observed data. To accomplish this goal, time series results from 3 experimental studies (Rivera-Torres et al., 2010b, 2011a, b) were used as observed values for calibration procedure.

\section{Experimental Data}

The model was calibrated on experimental data of male and female turkeys. For each of the 3 experimental studies used for calibration, the turkeys were grown under a controlled environment and fed standard diets; thus no environmental constraint was assumed to limit the expression of genetic potential. Two experimental studies consisted in energy and $\mathrm{N}$ balances that were carried out by indirect calorimetry on male medium-size turkeys (Rivera-Torres et al., 2010b) and males and females from a heavy strain (Rivera-Torres et al., 2011a) to partition ME intake into HP and energy retention as protein and lipid. The third study corresponded to serial slaughter analyses performed in medium-size male turkeys (Rivera-Torres et al., 2011b) to determine the contribution of carcass, viscera, and feather in total protein, lipid, ash, and water retention. The user-defined parameters (i.e., age at feed transition, and dietary DM, ME, CP, and crude fat contents) were taken from Rivera-Torres et al. (2011a).

The experimental data from the serial slaughter analyses corresponded to the observed mass of carcass, viscera, and feather in male turkeys and to the observed mass of protein, ash, and water in the carcass with viscera and in the feathers, along with the lipid mass in carcass with viscera $(\mathrm{g})$. The experimental data from the energy and $\mathrm{N}$ balances corresponded to the observed BW $(\mathrm{g})$, feed intake $(\mathrm{g} / \mathrm{d}), \mathrm{O}_{2}$ consumption $(\mathrm{L} / \mathrm{d}), \mathrm{CO}_{2}$ production $(\mathrm{L} / \mathrm{d})$, respiratory quotient, $\mathrm{ME}$ intake $(\mathrm{kJ} / \mathrm{d}), \mathrm{HP}(\mathrm{kJ} / \mathrm{d}), \mathrm{AA}(\mathrm{N} \times 6.25)$ intake, excretion in droppings $(\mathrm{g} / \mathrm{d})$, and protein and lipid retention $(\mathrm{g} / \mathrm{d})$. In addition, the oxidation rates of AA $\left(\mathbf{O X}_{\mathbf{P}}\right)$, carbohydrates $\left(\mathbf{O X}_{\mathbf{C H O}}\right.$, as Gl equivalent), and fat $\left(\mathbf{O X}_{\mathbf{F}}\right)$ into $\mathrm{CO}_{2}$ were calculated as suggested by Chwalibog and Thorbek (1999) in laying hens, assuming a zero egg production; the $\mathrm{OX}_{\mathrm{F}}, \mathrm{OX}_{\mathrm{CHO}}$, and $\mathrm{OX}_{\mathrm{P}}$ values calculated from the energy and $\mathrm{N}$ balances were used as observed values and compared with the simulated $\mathrm{OX}_{\mathrm{F}}, \mathrm{OX}_{\mathrm{CHO}}$, and $\mathrm{OX}_{\mathrm{P}}$ values. The simulated $\mathrm{OX}_{\mathrm{F}}, \mathrm{OX}_{\mathrm{CHO}}$, and $\mathrm{OX}_{\mathrm{P}}$ values were calculated from the simulated $\mathrm{OX}_{\mathrm{AA}}, \mathrm{OX}_{\mathrm{FA}}, \mathrm{OX}_{\mathrm{Gl}}$, and $\mathrm{OX}_{\mathrm{Ay}}$ by attributing the $\mathrm{OX}_{\mathrm{Ay}}$ to $\mathrm{OX}_{\mathrm{CHO}}, \mathrm{OX}_{\mathrm{F}}$, or $\mathrm{OX}_{\mathrm{P}}$, depending on the energetic contribution of $\mathrm{OX}_{\mathrm{AA}}, \mathrm{OX}_{\mathrm{FA}}$, and $\mathrm{OX}_{\mathrm{Gl}}$ in the production of Ay:

$\mathrm{OX}_{\mathrm{CHO}}=\mathrm{OX}_{\mathrm{Gl}} \times\left[1+\frac{1}{\left(\mathrm{OX}_{\mathrm{Gl}}+\mathrm{OX}_{\mathrm{FA}}+\mathrm{OX}_{\mathrm{AA}}\right)} \mathrm{OX}_{\mathrm{Ay}}\right]$;

$$
\begin{gathered}
\mathrm{OX}_{\mathrm{F}}=\mathrm{OX}_{\mathrm{FA}} \times \\
{\left[1+\frac{1}{\left(\mathrm{OX}_{\mathrm{Gl}}+\mathrm{OX}_{\mathrm{FA}}+\mathrm{OX}_{\mathrm{AA}}\right)} \mathrm{OX}_{\mathrm{Ay}}\right] \text {; and }} \\
\mathrm{OX}_{\mathrm{P}}=\mathrm{OX}_{\mathrm{AA}} \times\left[1+\frac{1}{\left(\mathrm{OX}_{\mathrm{Gl}}+\mathrm{OX}_{\mathrm{FA}}+\mathrm{OX}_{\mathrm{AA}}\right)} \mathrm{OX}_{\mathrm{Ay}}\right]
\end{gathered}
$$

\section{Calibration Procedure}

Model calibration consisted in defining the parameter values of both male and female growth profiles as a basis for further model evaluation of the effect of genotype and nutrition on each sex. Model calibration was mostly performed manually. Although labor intensive, manual iterations seemed to be most adapted to compare the model outputs with the large number of experimental data because successive computer-based optimizations of 1 or few parameters did not result in the optimum of all the parameter estimates. In addi- 
Table 1. Definition of the constant and fitted and user-defined parameters used in the turkey growth model

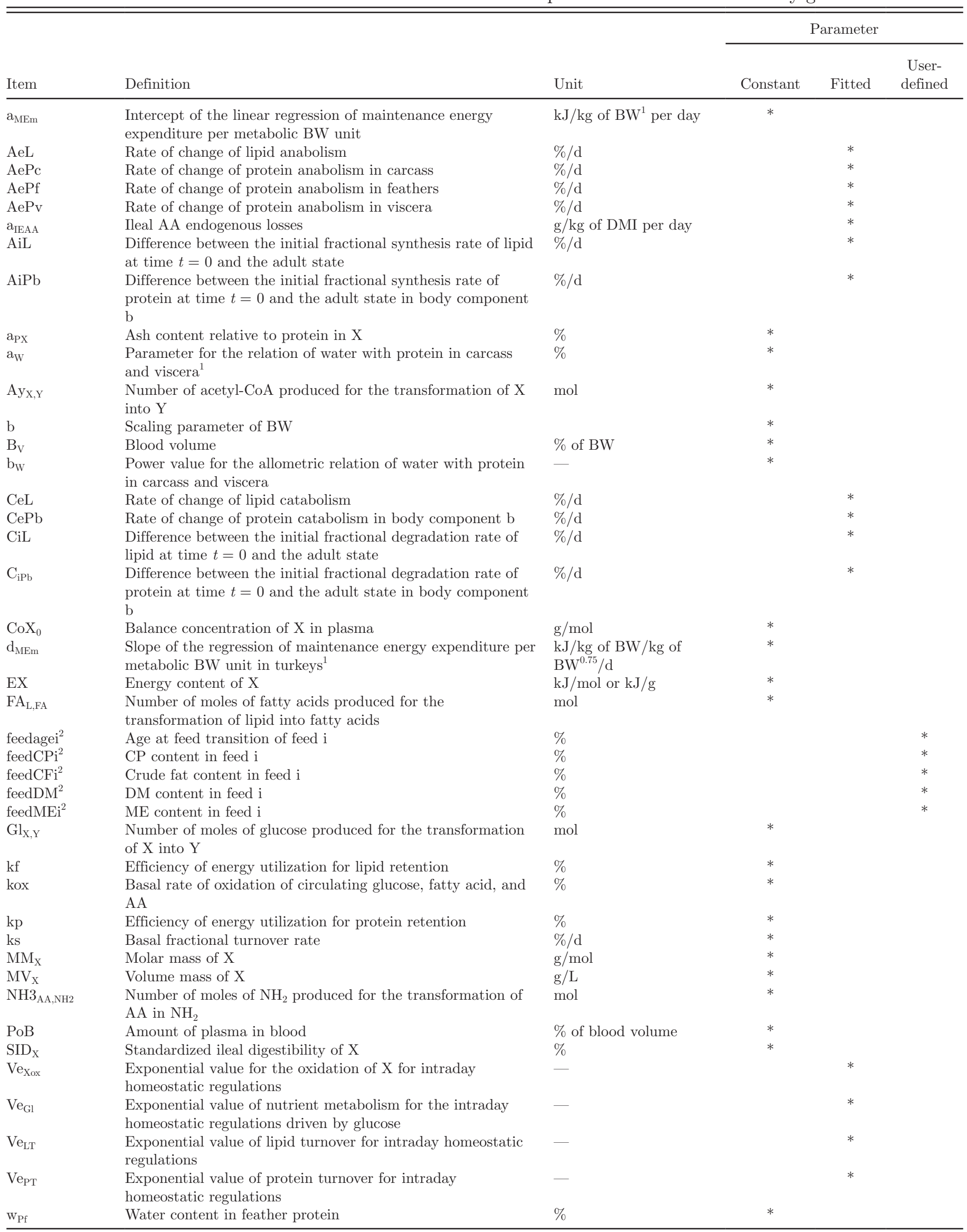

${ }^{1}$ The value may differ depending on sex.

${ }^{2}$ The number of parameters equals the number of feeds. 
Table 2. Constant parameters defined in the turkey growth model

\begin{tabular}{|c|c|c|}
\hline Constant parameter & Value $^{1}$ & References \\
\hline $\mathrm{a}_{\mathrm{IEAA}}$ & 6.5 & Adedokun et al. (2007b) \\
\hline $\mathrm{a}_{\mathrm{MEm}}$ & 628 & Rivera-Torres et al. (2011a) \\
\hline$a_{\mathrm{PCV}}$ & 17 & Rivera-Torres et al. (2011b) \\
\hline $\mathrm{a}_{\mathrm{Pf}}$ & 1.5 & Rivera-Torres et al. (2011b) \\
\hline $\mathrm{ATP}_{\mathrm{AA}, \mathrm{Ay}}$ & 14 & Gerrits et al. (1997) \\
\hline $\mathrm{ATP}_{\mathrm{Ay}, \mathrm{CO} 2}$ & 12 & Gerrits et al. (1997) \\
\hline $\operatorname{ATP}_{\mathrm{Ay}, \mathrm{FA}}$ & 1.13 & Gerrits et al. (1997) \\
\hline $\mathrm{ATP}_{\mathrm{FA}, \mathrm{Ay}}$ & 36 & Gerrits et al. (1997) \\
\hline $\mathrm{ATP}_{\mathrm{Gl}, \mathrm{Ay}}$ & 14 & Gerrits et al. (1997) \\
\hline $\mathrm{ATP}_{\mathrm{La}}$ & -10 & Gerrits et al. (1997) \\
\hline $\mathrm{ATP}_{\mathrm{Lc}}$ & 2.26 & Gerrits et al. (1997) \\
\hline $\mathrm{ATP}_{\mathrm{Pa}}$ & -5 & Gerrits et al. (1997) \\
\hline $\mathrm{ATP}_{\mathrm{Pc}}$ & -1 & Gerrits et al. (1997) \\
\hline$a_{W}$ & $290 / 341$ & Rivera-Torres et al. (2011b)/Emmans (1989) \\
\hline $\mathrm{Ay}_{\mathrm{AA}, \mathrm{Ay}}$ & 2.5 & Gerrits et al. (1997) \\
\hline $\mathrm{Ay}_{\mathrm{FA}, \mathrm{Ay}}$ & 9 & Gerrits et al. (1997) \\
\hline $\mathrm{Ay}_{\mathrm{Gl}, \mathrm{Ay}}$ & 2 & Gerrits et al. (1997) \\
\hline $\mathrm{b}$ & 0.75 & Rivera-Torres et al. (2010b) \\
\hline$b_{W}$ & $1 / 0.90$ & Rivera-Torres et al. (2011b)/Emmans (1989) \\
\hline $\mathrm{B}_{\mathrm{V}}$ & 7.2 & McCartney (1952) \\
\hline $\mathrm{C}_{\mathrm{AA} 0}$ & 0.7 & Geraert et al. (1987) \\
\hline $\mathrm{C}_{\mathrm{FA} 0}$ & 0.85 & Sato et al. (2008) \\
\hline $\mathrm{C}_{\mathrm{G} 10}$ & 2 & Geraert et al. (1987) \\
\hline $\mathrm{CO} 2_{\mathrm{Gl}, \mathrm{Ay}}$ & 2 & van Milgen (2002) \\
\hline $\mathrm{CO} 2_{\mathrm{Ay}, \mathrm{CO} 2}$ & 2 & van Milgen (2002) \\
\hline $\mathrm{d}_{\mathrm{MEm}}$ & $-5 /-13$ & Rivera-Torres et al. (2011a) \\
\hline $\mathrm{E}_{\mathrm{ATP}}$ & 79.5 & Campbell and Reece (2005) \\
\hline $\mathrm{E}_{\mathrm{Gl}}$ & 15.7 & Campbell and Reece (2005) \\
\hline $\mathrm{E}_{\mathrm{L}}$ & 39.6 & Rivera-Torres et al. (2010a) \\
\hline $\mathrm{E}_{\mathrm{P}}$ & 23.7 & Rivera-Torres et al. (2010a) \\
\hline $\mathrm{FA}_{\mathrm{L}, \mathrm{FA}}$ & 3 & Gerrits et al. (1997) \\
\hline $\mathrm{Gl}_{\mathrm{AA}, \mathrm{Gl}}$ & 0.83 & Gerrits et al. (1997) \\
\hline $\mathrm{Gl}_{\mathrm{FA}, \mathrm{Gl}}$ & 2.67 & Gerrits et al. (1997) \\
\hline $\mathrm{Gl}_{\mathrm{L}, \mathrm{Gl}}$ & 0.5 & Gerrits et al. (1997) \\
\hline $\mathrm{k}_{\mathrm{f}}$ & 96 & Rivera-Torres et al. (2011a) \\
\hline $\mathrm{k}_{\mathrm{ox}}$ & 2 & Gerrits et al. (1997) \\
\hline $\mathrm{k}_{\mathrm{p}}$ & 65 & Rivera-Torres et al. (2011a) \\
\hline $\mathrm{k}_{\mathrm{s}}$ & 1 & Lovatto and Sauvant (2003) \\
\hline $\mathrm{MM}_{\mathrm{AA}}$ & 125 & Campbell and Reece (2005) \\
\hline $\mathrm{MM}_{\mathrm{CO} 2}$ & 48 & Campbell and Reece (2005) \\
\hline $\mathrm{MM}_{\mathrm{FA}}$ & 282 & Campbell and Reece (2005) \\
\hline $\mathrm{MM}_{\mathrm{Gl}}$ & 180 & Campbell and Reece (2005) \\
\hline $\mathrm{MM}_{\mathrm{N}}$ & 14 & Campbell and Reece (2005) \\
\hline $\mathrm{MM}_{\mathrm{NH} 2}$ & 16 & Campbell and Reece (2005) \\
\hline $\mathrm{MM}_{\mathrm{O} 2}$ & 32 & Campbell and Reece (2005) \\
\hline $\mathrm{MM}_{\mathrm{TG}}$ & 884 & Campbell and Reece (2005) \\
\hline $\mathrm{MV}_{\mathrm{CO} 2}$ & 1.87 & Campbell and Reece (2005) \\
\hline $\mathrm{MV}_{\mathrm{O} 2}$ & 1.35 & Campbell and Reece (2005) \\
\hline $\mathrm{NH} 2_{\mathrm{AA}, \mathrm{NH} 2}$ & 1.4 & Campbell and Reece (2005) \\
\hline $\mathrm{O}_{2 \mathrm{Gl}, \mathrm{Ay}}$ & 2 & van Milgen (2002) \\
\hline $\mathrm{O}_{2 \mathrm{Ay}, \mathrm{CO} 2}$ & 2 & van Milgen (2002) \\
\hline $\mathrm{PoB}$ & 55 & Lovatto and Sauvant (2003) \\
\hline $\mathrm{SID}_{\mathrm{AA}}$ & 90 & Sauvant et al. (2004) \\
\hline $\mathrm{SID}_{\mathrm{CF}}$ & 85 & Honda et al. (2009) \\
\hline $\mathrm{w}_{\mathrm{Pf}}$ & 12.7 & Rivera-Torres et al. (2011b) \\
\hline
\end{tabular}

${ }^{1}$ Parameter values differ between sexes (male/female).

tion, the experimental data had to be interpreted individually rather than being considered as a set of average observed values with SD (i.e., protein retention rate in males was that of both medium-size and heavy genotypes, whereas protein mass of carcass with viscera was only that of a medium-size genotype).
The values of the HR and interday HS regulation parameters were first defined on male and female growth profiles, whereas no intraday HS regulation was considered. The results from the meta-analysis of the FSR and FDR of protein in broilers were used as a basis for calibrating the parameters associated with protein 
turnover. Similar to the FSR and FDR of lipid, the FSR of both feather and viscera protein were assumed independent of sex. The initial synthesis and degradation rates of protein were assumed to be 2- to 3 -fold greater in viscera than in carcass, whereas the initial synthesis rate of protein in feathers was assumed to be less than that in carcass. Also, because of the earlier development of viscera relative to carcass (Hurwitz et al., 1991), the FSR and FDR of viscera protein were assumed to decrease faster than those of carcass protein.

On the basis of the estimates of the parameters associated with the HR and interday HS regulations, the intraday HS regulation parameters were calibrated. These parameters were associated with the metabolic regulations of circulating nutrient concentrations; thus, they were assumed to be independent of sex and genotype. The observed $\mathrm{OX}_{\mathrm{CHO}}, \mathrm{OX}_{\mathrm{F}}$, and $\mathrm{OX}_{\mathrm{P}}$ values were used for manual calibration of the $\mathrm{Ve}_{\mathrm{Glox}}, \mathrm{Ve}_{\mathrm{FAox}}$, and $\mathrm{Ve}_{\mathrm{AAox}}$ parameters, respectively. It was assumed that the main driving forces associated with intraday HS regulations corresponded to the oxidation of circulating nutrient (i.e., AA, Gl, and FA). Thus, the $\mathrm{Ve}_{\mathrm{Glox}}$, $\mathrm{Ve}_{\mathrm{AAox}}$, and $\mathrm{Ve}_{\mathrm{FAox}}$ parameters were expected to have the greater values (i.e., greater than unity), whereas the $\mathrm{Ve}_{\mathrm{PT}}$ and $\mathrm{Ve}_{\mathrm{LT}}$ parameters were assumed to be less than unity. Finally, the $\mathrm{Ve}_{\mathrm{PT}}$ and $\mathrm{Ve}_{\mathrm{LT}}$ parameters were calibrated ultimately to maximize the goodness of fit of protein and lipid retention in both male and female growth profiles.

Sensitivity Analyses. The sensitivity analysis was performed on constant and fitted parameters to allow identifying the parameters that had a major influence on the model outputs. The analysis was performed on the parameters that regulate $\mathrm{BW}$ gain composition. Also, all the fitted parameters associated with the intraday HS regulations were analyzed because (contrary to the interday HS regulations) their values could not be calibrated or validated with biological observations. The sensitivity analysis evaluated the effect of a $5 \%$ (i.e., parameters less than unity) or $15 \%$ (i.e., parameters greater than unity) increase and decrease of the reference parameter values on major model outputs (e.g., protein retention, lipid retention, BW gain, and feed intake).

Statistical Analyses. The statistical analyses were performed to determine the accuracy of the model and to estimate the bias of simulation. The accuracy of the model defined how close the simulated values were to the observed values. The model was expected to be accurate from both a technical viewpoint (e.g., feed-to-gain ratio, BW gain) and a nutritional one (e.g., nutrient oxidation, $\mathrm{CO}_{2}$ production). To observe the accuracy of the model at the different levels of organization of the turkey, the observed values (Y-variate) were plotted against the simulated values (X-variate) of the different outputs of the model. The simulated values were plotted on the $\mathrm{X}$-variate because they corresponded to deterministic values, whereas the observed values were stochastic (i.e., replicate measurements). A linear regression was performed to estimate the intercept and the slope ( $b$ value) of the linear regression of the $\mathrm{Y}$ variate on the $\mathrm{X}$-variate. Accurate simulations should result in an intercept and a regression slope close to zero and unity, respectively, and in a high coefficient of determination.

To evaluate the bias of simulation, the mean square prediction error (MSPE) was calculated. The MSPE was defined as follows (Tedeschi, 2006):

$$
\operatorname{MSPE}=(\overline{\mathrm{X}}-\overline{\mathrm{Y}})^{2}+\delta_{\mathrm{X}}^{2} \times(1-\mathrm{b})^{2}+\left(1-\mathrm{r}^{2}\right) \times \delta_{\mathrm{Y}}^{2} .
$$

The first term of this equation $\left[(\bar{X}-\bar{Y})^{2}\right]$ represented the mean bias of the simulated values and indicated an eventual over or underestimation of the observations. The second term $\left[\delta_{\mathrm{X}}^{2} \times(1-\mathrm{b})^{2}\right]$ corresponded to the bias of regression (i.e., deviation of the slope from unity), whereas the third term referred to the random errors unrelated to the error of simulation. The root MSPE was used so that it was expressed as the same unit as the observed values. Also, each of the 3 terms of the MSPE was expressed as a percentage of the total MSPE to interpret the source of error. Accurate simulations were expected to have a small MSPE (i.e., or root MSPE) and small mean bias and bias of regression.

\section{Model Evaluation}

Response to Genotype. Based on the average male and female growth profiles, simulations were performed on different genotypes of both sexes to evaluate the flexibility of the model to adapt to different genotypes. Similar to the male and female growth profiles defined during calibration, we assumed similar fractional turnover rates of protein in viscera and feathers among turkey individuals. Also, the FDR of lipid was assumed independent of genotype. The adjustment among genotypes of a same sex, therefore, included the $\mathrm{Ai}_{\mathrm{Pc}}, \mathrm{Ae}_{\mathrm{Pc}}, \mathrm{Ci}_{\mathrm{Pc}}, \mathrm{Ce}_{\mathrm{Pc}}, \mathrm{Ai}_{\mathrm{L}}$, and $\mathrm{Ae}_{\mathrm{L}}$ parameters. The genotypes of the male (Nicholas 700, Aviagen Turkeys Ltd., Tattenhall, Cheshire, UK) and the female (Hybrid Converter, Hybrid Turkeys, Kitchener, Ontario, Canada) strains were used for evaluation. Feed characteristics, daily BW gain $(\mathrm{g} / \mathrm{d})$, feed intake $(\mathrm{g} / \mathrm{d})$, and feed conversion $(\mathrm{g} / \mathrm{g})$ expectations were those of the breeding company. The results from the evaluation were performed following the statistical analyses described in model calibration.

Response to Nutrition. The accuracy of the model to predict the response to changing energy or nutrient content was tested by comparing the model simulations with experimental data. The results from the measurements made on male turkeys from 4 to 16 wk of age (Veldkamp et al., 2005) were used for this evaluation. To use the model as a prediction tool of the response to nutrition, we first performed an adjustment of the growth profile to the daily BW gain, feed intake, 
and feed-to-gain ratio measured in the control treatment [E100, with Lys content at 105\% of NRC (1994) recommendations]. We assumed that all the turkeys were given a control diet that corresponded to 0 to 4 wk of age (NRC, 1994).

The model predictions consisted of comparing the predicted outputs with the observed daily BW gain, feed intake, and feed-to-gain ratio of the treatments, after modification of the user-defined parameters associated with the feed characteristics (i.e., ME levels). The treatments tested corresponded to 90 and $110 \%$ of the $\mathrm{ME}$ of the control treatment (i.e., treatments E90 and E110, respectively). Statistical analyses were performed as described in model calibration.

\section{RESULTS}

\section{Model Calibration}

Model Behavior. The results from the calibration agreed with the observed values from all 3 experimental studies. The modeling of energy and nutrient utilization allowed us to simulate the change in the retention rates of protein, lipid, ash, and water in carcass, viscera, and feathers of male and female turkeys during growth. As expected, carcass gain was greater than viscera gain. The growth rate of viscera was maximized at $6 \mathrm{wk}$ of age in both male and female turkeys, and it then transiently stabilized after 11 wk of age when the carcass growth rate was maximized (Figure 3 ).

The calibration on both sexes was a means to define some differences in the outcomes of HR and HS regulations among males and females. Female turkeys had a decreased carcass gain but a greater viscera gain in comparison with males because of the greater mass of viscera protein relative to the mass of carcass protein.
Male turkeys deposited more protein and less lipid than females, resulting in a decreased feed-to-gain ratio, as indicated by the observed values. The greater protein retention and the reduced lipid retention in male turkeys were due to the greater FSR of protein and to the decreased FSR of lipid in comparison with females. Also, the FDR of carcass protein in females was less than that in males. In addition to the maintenance energy expenditure and the allometric relation of water with protein (i.e., $\mathrm{d}_{\mathrm{MEm}}$ and $\mathrm{W}_{\mathrm{PCV}}$ were constant parameters), 6 fitted parameters related to the HR and interday HS regulations characterized the difference between the growth profiles of males and females (Table 3 ). These parameters corresponded to the FSR and FDR of carcass protein (i.e., $\mathrm{Ai}_{\mathrm{P}_{\mathrm{c}}}, \mathrm{Ae}_{\mathrm{Pc}}, \mathrm{Ci}_{\mathrm{P}_{\mathrm{P}}}$, and $\mathrm{Ce}_{\mathrm{Pc}}$, respectively) and the FSR of lipid (i.e., $\mathrm{Ai}_{\mathrm{L}}$ and $\mathrm{Ae}_{\mathrm{L}}$ ) as defined during model calibration.

The fitted parameters associated with protein turnover in carcass, viscera, and feathers resulted in FSR and FDR estimates of carcass and viscera protein that were close to those measured by Kang et al. (1985a) in the breast muscle of turkeys after 2 wk of age (Figure 4). However, the simulated FSR of protein in carcass before 2 wk of age seemed to be less than those measured by the same authors in breast and thigh of turkeys. Also, the FDR of carcass determined by the model was similar to turkeys younger than 8 wk of age as reported by Kang et al. (1985a).

The intraday HS regulations ensured the maintenance of a constant concentration of circulating nutrients, primarily through the regulation of nutrient oxidation (i.e., $\mathrm{Ve}_{\mathrm{Glox}}, \mathrm{Ve}_{\mathrm{AAox}}, \mathrm{Ve}_{\mathrm{FAox}}$ ), and partly through the control of protein and lipid turnovers in carcass and viscera (i.e., $\mathrm{Ve}_{\mathrm{PT}}$, and $\mathrm{Ve}_{\mathrm{LT}}$ ), as illustrated by the greater $\mathrm{Ve}_{\mathrm{Glox}}, \mathrm{Ve}_{\mathrm{AAox}}$, and $\mathrm{Ve}_{\mathrm{FAox}}$ values in comparison with the $\mathrm{Ve}_{\mathrm{PT}}$ and $\mathrm{Ve}_{\mathrm{LT}}$ values (Table 3). The $\mathrm{Ve}_{\mathrm{Glox}}$

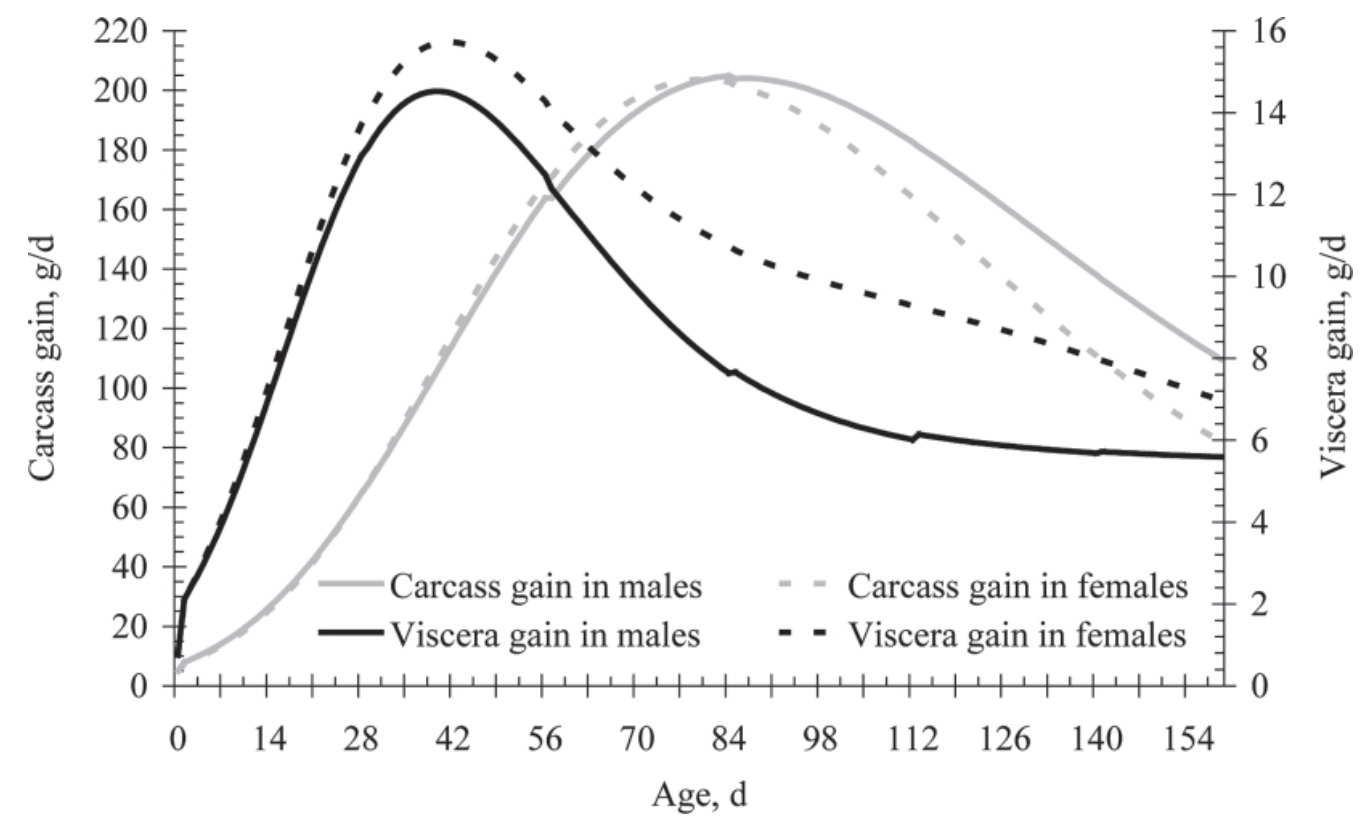

Figure 3. Carcass and viscera growth rates in male and female growing turkeys with age. 


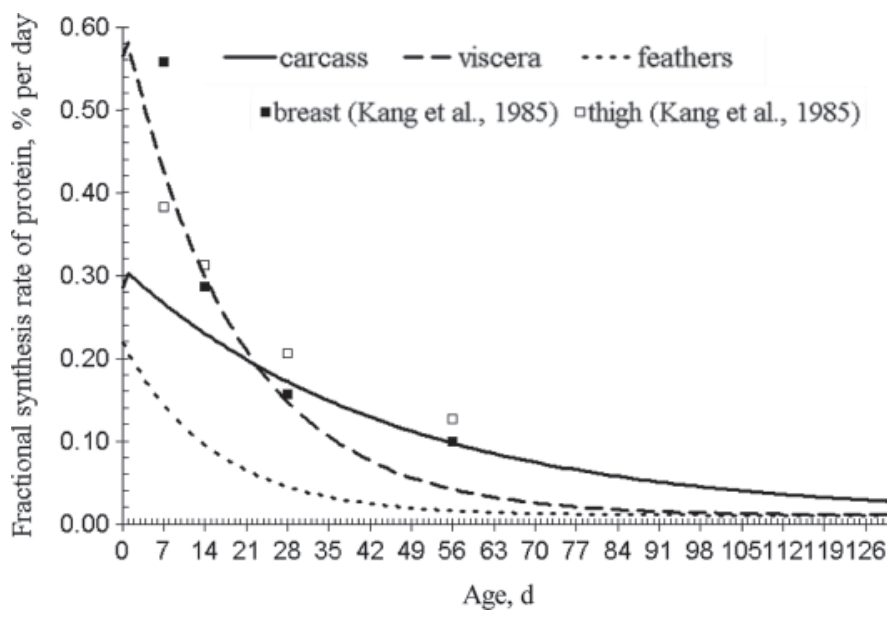

Figure 4. Fractional synthesis rate (FSR) of protein in carcass, viscera, and feathers with age in male growing turkeys (Kang et al., 1985a).

parameter was greater than $\mathrm{Ve}_{\mathrm{AAox}}$ and $\mathrm{Ve}_{\mathrm{FAox}}$ because the $\mathrm{OX}_{\mathrm{CHO}}$ determined from the experimental data was greater than $\mathrm{OX}_{\mathrm{P}}$ and $\mathrm{OX}_{\mathrm{F}}$. The $\mathrm{Ve}_{\mathrm{LT}}$ parameter estimate was greater than $\mathrm{Ve}_{\mathrm{PT}}$ because lipid turnover was greater than $\mathrm{Ve}_{\mathrm{PT}}$. Also, the energy provided in excess was primarily stored as lipid, whereas most of the AA in excess were deaminated and used as energy source. The adaptation of protein turnover to the circulating AA concentration intervened as a minor regulation be- cause it was limited by the HR and interday HS regulations, which both defined protein retention rate on a long-term scale.

Accuracy and Bias of Model Outputs. The accuracy of the technical outputs of the model was illustrated by increased coefficients of determination for daily BW gain, feed intake, $\mathrm{N}$ utilization, and energy utilization in male and female turkeys. The MSPE were small in both males and females relative to the mean observed values. The MSPE were globally greater in males in comparison with females, averaging 25 and $10 \%$ of the mean observed values of males and females, respectively. The major simulation errors were associated with daily BW gain, lipid retention and mass, and feather mass components in male turkeys (Table 4). However, similar to the other simulated values, the MSPE were mostly due to unexplained variations, which means that the mean bias and regression bias remained low relative to the variability of the observed values. The unexplained variations exceeded $50 \%$ of the MSPE, except for simulated HP in females (Table 5), which showed a consistent underestimation (i.e., $55.0 \%$ of the MSPE was associated with mean bias). Similar observations were made when simulating $\mathrm{HP}$ in male turkeys.

In males, protein and lipid retention showed a consistent underestimation (i.e., increased mean bias relative to total MSPE), whereas these outputs were accurately

Table 3. Fitted parameters associated with protein and lipid turnover in male and female growing turkeys ${ }^{1}$

\begin{tabular}{|c|c|c|c|}
\hline \multirow[b]{2}{*}{ Parameter } & \multicolumn{2}{|c|}{ Value } & \multirow[b]{2}{*}{ Regulation $^{2}$} \\
\hline & Male & Female & \\
\hline \multicolumn{4}{|c|}{ Fractional rate of change, $\% / d$} \\
\hline $\mathrm{Ae}_{\mathrm{L}}$ & 2.0 & 1.9 & $\mathrm{HR} / \mathrm{HS}_{\mathrm{d}}$ \\
\hline$A e_{\mathrm{Pc}}$ & 2.2 & 2.8 & $\mathrm{HR} / \mathrm{HS}_{\mathrm{d}}$ \\
\hline $\mathrm{Ae}_{\mathrm{Pf}}$ & \multicolumn{2}{|c|}{6.4} & $\mathrm{HR}$ \\
\hline$A e_{\mathrm{Pv}}$ & \multicolumn{2}{|c|}{5.3} & HR \\
\hline $\mathrm{Ce}_{\mathrm{L}}$ & \multicolumn{2}{|c|}{2.8} & HR \\
\hline $\mathrm{Ce}_{\mathrm{Pc}}$ & 2.3 & 4.0 & $\mathrm{HR} / \mathrm{HS}_{\mathrm{d}}$ \\
\hline $\mathrm{Ce}_{\mathrm{Pv}}$ & \multicolumn{2}{|c|}{6.3} & $\mathrm{HR}$ \\
\hline \multicolumn{4}{|c|}{$\begin{array}{l}\text { Difference in fractional turnover rate between } \\
\text { the initial state and the adult state, } \% / \mathrm{d}\end{array}$} \\
\hline $\mathrm{Ai}_{\mathrm{L}}$ & 10.0 & 12.4 & $\mathrm{HR} / \mathrm{HS}_{\mathrm{d}}$ \\
\hline $\mathrm{Ai}_{\mathrm{Pc}}$ & 27.3 & 25.4 & $\mathrm{HR} / \mathrm{HS}_{\mathrm{d}}$ \\
\hline $\mathrm{Ai}_{\mathrm{Pf}}$ & \multicolumn{2}{|c|}{21.0} & $\mathrm{HR}$ \\
\hline $\mathrm{Ai}_{\mathrm{Pv}}$ & \multicolumn{2}{|c|}{55.0} & HR \\
\hline $\mathrm{Ci}_{\mathrm{L}}$ & \multicolumn{2}{|c|}{2.0} & HR \\
\hline $\mathrm{Ci}_{\mathrm{Pc}}$ & 18.0 & 17.0 & $\mathrm{HR} / \mathrm{HS}_{\mathrm{d}}$ \\
\hline $\mathrm{Ci}_{\mathrm{Pv}}$ & \multicolumn{2}{|c|}{50.0} & $\mathrm{HR}$ \\
\hline \multicolumn{4}{|c|}{ Intraday homeostatic regulations } \\
\hline $\mathrm{Ve}_{\mathrm{AAox}}$ & \multicolumn{2}{|c|}{3.0} & $\mathrm{HS}_{\mathrm{m}}$ \\
\hline$V_{\text {FAox }}$ & \multicolumn{2}{|c|}{7.0} & $\mathrm{HS}_{\mathrm{m}}$ \\
\hline $\mathrm{Ve}_{\mathrm{Gl}}$ & \multicolumn{2}{|c|}{0.2} & $\mathrm{HS}_{\mathrm{m}}$ \\
\hline $\mathrm{Ve}_{\text {Glox }}$ & \multicolumn{2}{|c|}{10.0} & $\mathrm{HS}_{\mathrm{m}}$ \\
\hline $\mathrm{Ve}_{\mathrm{LT}}$ & \multicolumn{2}{|c|}{0.1} & $\mathrm{HS}_{\mathrm{m}}$ \\
\hline $\mathrm{Ve}_{\mathrm{PT}}$ & \multicolumn{2}{|c|}{0.03} & $\mathrm{HS}_{\mathrm{m}}$ \\
\hline
\end{tabular}


Table 4. Mean observed values, coefficient of determination $\left(\mathrm{R}^{2}\right)$, root mean square prediction error (MSPE), and decomposition of MSPE of simulated outputs in male turkeys until 23 wk of age

\begin{tabular}{|c|c|c|c|c|c|c|c|}
\hline Item & $\mathrm{n}$ & $\begin{array}{c}\text { Mean } \\
\text { observed } \\
\text { value }\end{array}$ & $\mathrm{R}^{2}, \%$ & $\begin{array}{l}\text { Root } \\
\text { MSPE }\end{array}$ & $\begin{array}{l}\text { Mean bias, } \\
\% \text { MSPE }\end{array}$ & $\begin{array}{c}\text { Regression } \\
\text { bias, } \\
\% \text { MSPE }\end{array}$ & $\begin{array}{c}\text { Unexplained } \\
\text { variation, } \\
\text { \% MSPE }\end{array}$ \\
\hline Daily BW gain, g/d & 36 & 146 & 47.3 & 48 & 3.2 & 12.5 & 84.4 \\
\hline Feed intake, $\mathrm{g} / \mathrm{d}$ & 36 & 397 & 93.3 & 49 & 1.2 & 0.0 & 98.8 \\
\hline Feed-to-gain ratio, $\mathrm{g} / \mathrm{g}$ & 36 & 2.762 & 73.0 & 0.861 & 11.3 & 18.5 & 70.1 \\
\hline $\mathrm{N}$ excretion, $\mathrm{g} / \mathrm{d}$ & 36 & 7.4 & 91.0 & 1.1 & 12.5 & 0.6 & 86.9 \\
\hline Heat production, $\mathrm{kJ} / \mathrm{d}$ & 36 & 3,506 & 97.1 & 358 & 23.8 & 0.2 & 76.0 \\
\hline $\mathrm{CO}_{2}$ production, $\mathrm{L} / \mathrm{d}$ & 36 & 163 & 96.9 & 16 & 0.7 & 7.4 & 91.9 \\
\hline \multicolumn{8}{|l|}{ Rivera-Torres et al. (2010b) } \\
\hline Carcass mass, g & 32 & 5,325 & 97.6 & 813 & 0.0 & 29.8 & 70.2 \\
\hline Viscera mass, g & 32 & 580 & 89.7 & 144 & 3.4 & 9.7 & 86.9 \\
\hline Protein in feathers, $g$ & 32 & 166 & 86.3 & 57.1 & 16.9 & 20.3 & 62.8 \\
\hline Water in feathers, $g$ & 32 & 22.2 & 87.0 & 8.9 & 18.7 & 31.3 & 50.0 \\
\hline Ash in feathers, $g$ & 32 & 2.3 & 82.4 & 0.6 & 0.9 & 0.7 & 98.4 \\
\hline
\end{tabular}

simulated in females (i.e., the root MSPE equaled 16 and $48 \mathrm{~g} / \mathrm{d}$ in females and males, respectively). As a result of the underestimation of protein and lipid retention in males, BW gain was globally underestimated until $150 \mathrm{~g} / \mathrm{d}$. Thereafter, it was underestimated in heavy male turkeys, whereas it was overestimated in medium-size turkeys (Figure 5).

Sensitive Parameters. The sensitivity analysis showed that the parameters defining ME intake regulation (i.e., $\mathrm{a}_{\mathrm{MEm}}, \mathrm{k}_{\mathrm{p}}$, and $\mathrm{k}_{\mathrm{f}}$ ) and carcass protein turnover (i.e., $\mathrm{Ai}_{\mathrm{Pc}}, \mathrm{Ci}_{\mathrm{Pc}}, \mathrm{Ae}_{\mathrm{Pc}}$, and $\mathrm{Ce}_{\mathrm{Pc}}$ ) had a major effect on the model outputs (Table 6). As expected, increasing the $\mathrm{a}_{\mathrm{MEm}}$ value by $15 \%$ resulted in increased ME intake (and thus feed intake) because of greater maintenance energy expenditure. On the contrary, increasing the $\mathrm{k}_{\mathrm{p}}$ or $\mathrm{k}_{\mathrm{f}}$ value resulted in a decrease of both $\mathrm{ME}$ and feed intake because of the decreased heat production associated with protein and lipid retention.

The parameters associated with carcass protein turnover affected both BW gain and feed intake (Table 6). Increasing the $\mathrm{Ai}_{\mathrm{Pc}}$ parameter by $5 \%$ resulted in increased anabolic flows of protein in carcass (i.e., +89.1 $\mathrm{g} / \mathrm{d}$ ), and thus in increased BW gain (i.e., $+60.9 \mathrm{~g} / \mathrm{d}$ ) and feed intake (i.e., $+207.7 \mathrm{~g} / \mathrm{d}$ ). On the contrary, increasing the $\mathrm{Ci}_{\mathrm{Pc}}$ parameter by $5 \%$ resulted in increased catabolic flow of carcass protein, and thus decreased protein retention, BW gain, and feed intake by 12.9 , 57.3 , and $89.6 \mathrm{~g} / \mathrm{d}$, respectively. Similarly, the $\mathrm{Ae}_{\mathrm{Pc}}$ and $\mathrm{Ce}_{\mathrm{Pc}}$ parameters strongly affected BW gain and feed intake by modifying the protein retention rate in carcass. In comparison with protein turnover, changes in the parameters associated with lipid turnover did not result in a major effect on lipid retention and feed intake.
The Ve parameters associated with the intraday HS regulations affected the growth response of the turkey to genotype and nutrition because these parameters were at the origin of the daily partitioning of the nutrients ingested among retention as protein and lipid, and dissipation as heat of AA, FA, and Gl origin. Increasing or decreasing the values of the Ve parameters by $15 \%$ mostly affected protein retention and thus BW gain and feed intake (Table 7) during all the observed growing period. More specifically, increasing the $\mathrm{Ve}_{\mathrm{Glox}}$, $\mathrm{Ve}_{\mathrm{AAox}}$, or $\mathrm{Ve}_{\mathrm{FAox}}$ parameter resulted in an increase in the corresponding oxidation rate (i.e., $\mathrm{OX}_{\mathrm{CHO}}, \mathrm{OX}_{\mathrm{P}}$, or

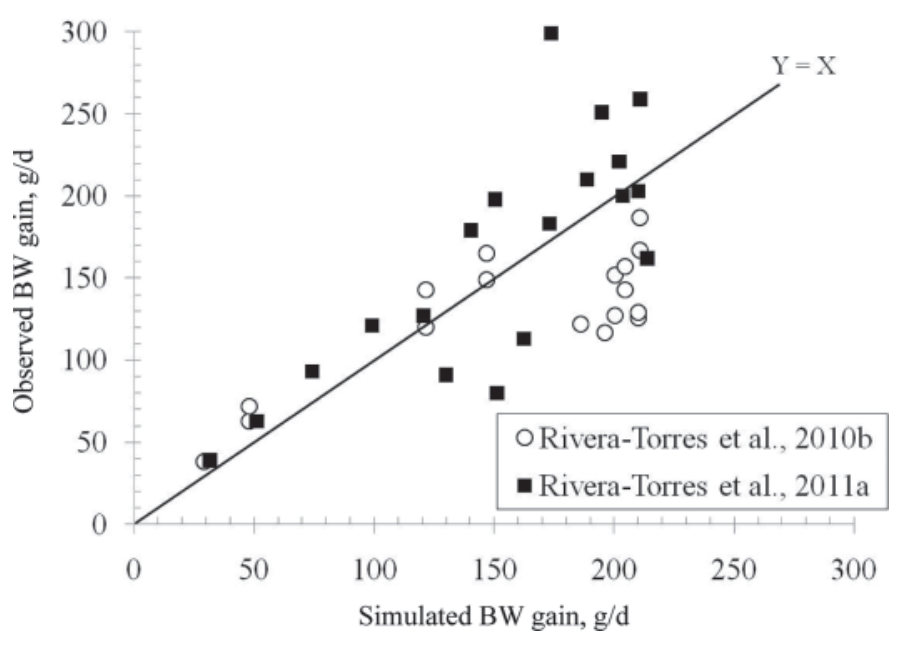

Figure 5. Observed and simulated BW gain (g/d) of male turkeys (Rivera-Torres et al., 2010b, 2011a). The straight regression line $(\mathrm{Y}=$ $\mathrm{X}$ ) represents the expected simulated values for which observed values (Y) equal simulated values (X). 
Table 5. Mean observed values, coefficient of determination $\left(\mathrm{R}^{2}\right)$, root mean square prediction error (MSPE), and decomposition of MSPE of simulated outputs in female turkeys from 0 to 23 wk of age (Rivera-Torres et al., 2011a)

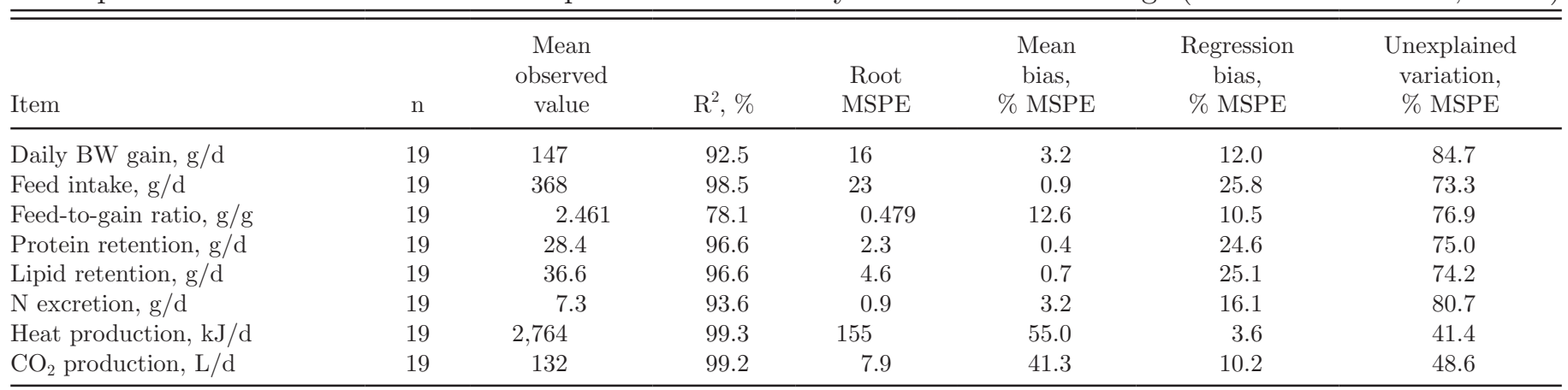

$\mathrm{OX}_{\mathrm{F}}$, respectively) at the expense of protein and lipid retention, and thus feed intake.

The parameters associated with AA oxidation (i.e., $\mathrm{Ve}_{\mathrm{AAox}}$ ) and protein turnover (i.e., $\mathrm{Ve}_{\mathrm{PT}}$ ) had the greater effects on the model outputs. An increase in the $\mathrm{Ve}_{\mathrm{AAox}}$ parameter resulted in a decrease in daily $\mathrm{BW}$ gain, mostly because of a decreased protein retention, which was due to a greater oxidation of the $\mathrm{AA}$ in excess and a decreased amount of AA integrated in protein turnover (i.e., greater $\mathrm{Ve}_{\mathrm{AAox}}-\mathrm{to}-\mathrm{Ve}_{\mathrm{PT}}$ ratio). As a consequence of the decreased protein retention (and BW gain), feed intake was also decreased. An increase in the $\mathrm{Ve}_{\mathrm{PT}}$ parameter was associated with greater protein retention due to an increase in protein synthesis and a decrease in protein degradation. Consequently, increasing the priority for protein turnover relative to nutrient oxidation resulted in a greater $\mathrm{BW}$ gain and feed intake.

\section{Model Evaluation}

Response to Genotype. The application of the model on different genotypes showed its ability to adapt to both male and female growth trajectories. The growth trajectories of the male (Nicholas 700) and the female (Hybrid Converter) strains were globally in accordance with the observed daily BW gain, feed intake, and feed-to-gain ratio. The coefficients of determination were greater in the simulations performed in females in comparison with males (Table 8). In females, the root-MSPE of BW gain and feed intake were both less than those observed in males (i.e., 4 and 23 vs. 10 and $46 \mathrm{~g} / \mathrm{d}$, respectively). The greater error of simulation was observed for the feed-to-gain ratio because it cumulated the simulation errors of both BW gain and feed intake. In both sexes, the errors of simulation of BW gain were mostly due to unexplained variation; the regression bias represented more than $55 \%$ of the MSPE of feed intake and feed-to-gain ratio.

In the genotype of males (Nicholas 700), the regression bias was due to an overestimation of the feed-togain ratio at early ages and to an underestimation at later ages (i.e., after 11 wk of age; Figure 6). The error of simulation (i.e., difference between simulated and observed values) of the feed-to-gain ratio averaged 0.004 $\mathrm{g} / \mathrm{g}$ between 1 to 22 wk of age. The error of simulation of the feed-to-gain ratio of the male genotype was particularly large before $5 \mathrm{wk}$ of age, averaging $0.396 \mathrm{~g} / \mathrm{g}$.

Table 6. Sensitivity analysis of protein retention, lipid retention, BW gain, and feed intake $(\mathrm{g} / \mathrm{d})$ to the fitted parameters associated with HR regulations in male growing turkeys at $77 \mathrm{~d}$ of age

\begin{tabular}{|c|c|c|c|c|c|c|c|}
\hline $\begin{array}{l}\text { Fitted } \\
\text { parameter }\end{array}$ & $\begin{array}{l}\text { Change, } \\
\%\end{array}$ & Main transaction & $\begin{array}{l}\text { Protein } \\
\text { retention, } \\
\mathrm{g} / \mathrm{d}\end{array}$ & $\begin{array}{l}\text { Lipid retention, } \\
\text { g/d }\end{array}$ & $\begin{array}{c}\text { BW } \\
\text { gain, } \\
\text { g/d }\end{array}$ & $\begin{array}{c}\text { Feed } \\
\text { intake, } \\
\mathrm{g} / \mathrm{d}\end{array}$ & $\begin{array}{c}\text { Effect } \\
\text { of main } \\
\text { transaction }\end{array}$ \\
\hline \multirow[t]{2}{*}{$\mathrm{a}_{\mathrm{MEm}}$} & -15 & \multirow[t]{2}{*}{ ME intake, kJ/d } & -1.6 & -2.9 & -9.2 & -57.0 & -716 \\
\hline & +15 & & +1.3 & +2.0 & +7.4 & +54.3 & +682 \\
\hline \multirow[t]{2}{*}{$\mathrm{k}_{\mathrm{p}}$} & -15 & \multirow[t]{2}{*}{ ME intake, kJ/d } & +1.6 & +1.9 & +8.4 & +43.0 & +540 \\
\hline & +15 & & -1.3 & -1.6 & -7.1 & -42.3 & -405 \\
\hline \multirow[t]{2}{*}{$\mathrm{k}_{\mathrm{f}}$} & -15 & \multirow[t]{2}{*}{ ME intake, kJ/d } & +0.5 & +0.9 & +3.0 & +20.9 & +262 \\
\hline & +15 & & -0.4 & -0.7 & -2.4 & -15.2 & -191 \\
\hline \multirow[t]{2}{*}{$\mathrm{Ae}_{\mathrm{Pc}}$} & -5 & Carcass protein & +28.9 & +2.5 & +120.1 & +142.7 & +57.2 \\
\hline & +5 & anabolism, g/d & -17.7 & -4.7 & -76.7 & -107.2 & -37.2 \\
\hline \multirow[t]{2}{*}{$\mathrm{Ai}_{\mathrm{Pc}}$} & -5 & Carcass protein & -21.2 & -8.0 & -94.5 & -151.9 & -50.9 \\
\hline & +5 & anabolism, g/d & +38.8 & +3.1 & +60.9 & +207.7 & +89.1 \\
\hline \multirow[t]{2}{*}{$\mathrm{Ci}_{\mathrm{Pc}}$} & -5 & Carcass protein & +17.9 & +2.2 & +74.9 & +101.7 & +20.1 \\
\hline & +5 & catabolism, g/d & -12.9 & -4.7 & -57.3 & -89.6 & -15.8 \\
\hline \multirow[t]{2}{*}{$\mathrm{Ce}_{\mathrm{Pc}}$} & -5 & Carcass protein & -11.2 & -3.5 & -49.0 & -68.1 & -8.1 \\
\hline & +5 & catabolism, g/d & +13.3 & +1.7 & +55.9 & +69.5 & +8.5 \\
\hline
\end{tabular}


Table 7. Sensitivity analysis of protein retention, lipid retention, BW gain, and feed intake (in g/d) to the fitted parameters associated with intraday homeostatic regulations in male growing turkeys at $77 \mathrm{~d}$ of age

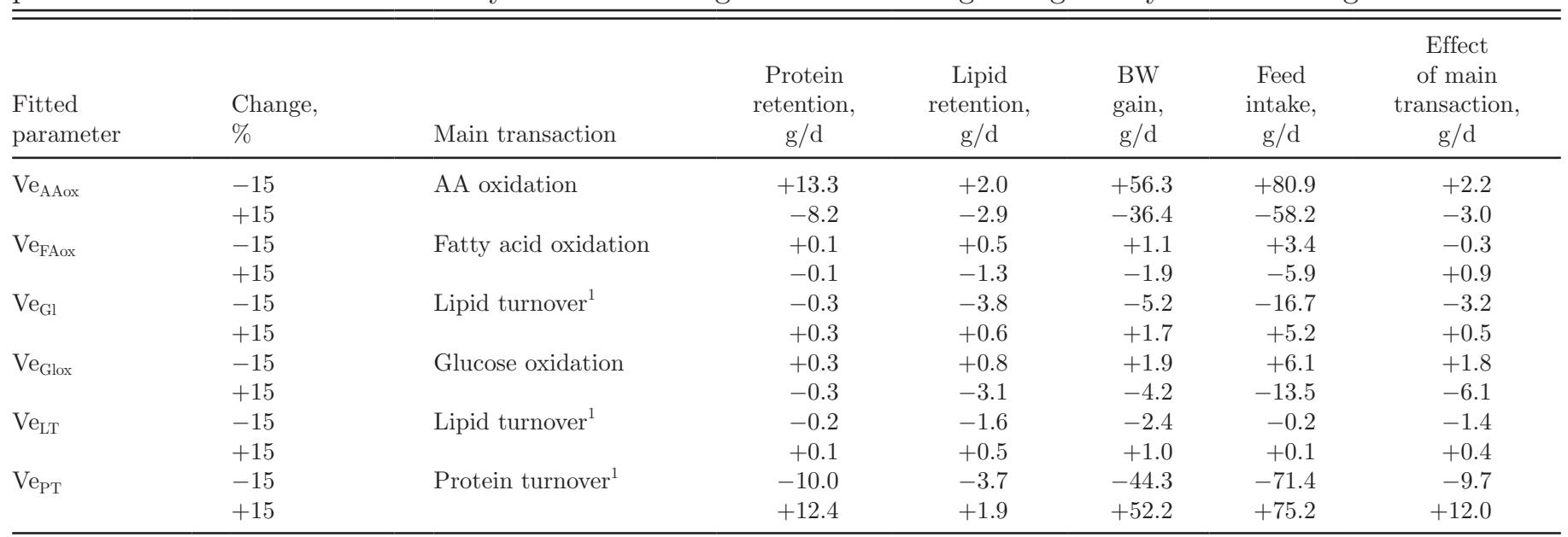

${ }^{1}$ The effect of main transaction was calculated from the synthesis and degradation rates of protein or lipid in carcass.

The daily BW gain in the genotype of females (Hybrid Converter) was alternately overestimated from 4 to 8 wk of age and after 16 wk of age (Figure 7). The average error of simulation of daily BW gain (i.e., difference between simulated and observed values) was $1.0 \mathrm{~g} / \mathrm{d}$ and varied from -6 to $+7 \mathrm{~g} / \mathrm{d}$ from 0 to 20 wk of age.

Response to Nutrition. The prediction of the effect of different ME (and crude fat content) was in accordance with the observed daily BW gain, feed intake, and feed-to-gain ratio (Figure 8). As expected, increasing the dietary ME decreased feed intake and feed-togain ratio, whereas the reverse was true when dietary ME was decreased. In addition to the observations made by Veldkamp et al. (2005) during the study, the model showed that decreasing the ME to $90 \%$ of the control treatment resulted in reduced lipid retention, in spite of a daily BW gain close to that of the control treatment. The turkeys fed diets with reduced ME were therefore shown to be leaner than those fed ME at 100 and $110 \%$ of the control treatment. Although the feedto-gain ratio was less in the turkeys fed ME at $110 \%$ of the control, these turkeys were less efficient in using nutrients for BW gain because they deposited more fat.

\section{DISCUSSION}

The model is capable of simulating the average growth response of a population of male and female turkeys to genetic and nutrition in a controlled (i.e., indirect calorimetry chambers) and experimental environment. Contrary to models based on empirical definitions of BW gain composition (Hurwitz et al., 1983; Emmans, 1989; King, 2001), the model was capable of simulating the differences in BW gain composition depending on feed ingredients, energy, and nutrient utilization. It was developed based on the hypothesis that differences in growth rate and feed-to-gain ratio are mainly due to the partitioning of energy retention between protein and lipid. In these conditions, no nutrient should be limiting in the diets.

The evaluation on both male and female genotypes showed the ability of the model to simulate the response of different genotypes of male and female turkeys to nutrition. The flexibility of the model was enabled by the mechanistic simulation of the interday and intraday HS regulations associated with energy and nutrient utilization. Both regulations were considered because the

Table 8. Mean observed values, coefficient of determination $\left(\mathrm{R}^{2}\right)$, root mean square prediction error (MSPE), and decomposition of MSPE of simulated outputs of 2 different sexes and genotypes of turkeys

\begin{tabular}{|c|c|c|c|c|c|c|c|}
\hline Item $^{1}$ & $\mathrm{n}$ & $\begin{array}{c}\text { Mean } \\
\text { observed } \\
\text { value }\end{array}$ & $\mathrm{R}^{2}$ & $\begin{array}{l}\text { Root } \\
\text { MSPE }\end{array}$ & $\begin{array}{l}\text { Mean bias, } \\
\% \text { MSPE }\end{array}$ & $\begin{array}{c}\text { Regression } \\
\text { bias, } \\
\% \text { MSPE }\end{array}$ & $\begin{array}{c}\text { Unexplained } \\
\text { variation, } \\
\text { \% MSPE }\end{array}$ \\
\hline BW gain, g/d & 22 & 146 & 92.6 & 10 & 6.0 & 1.5 & 92.6 \\
\hline Feed-to-gain ratio, g/g & 22 & 2.526 & 39.6 & 0.250 & 0.6 & 59.8 & 39.6 \\
\hline Feed intake, $\mathrm{g} / \mathrm{d}$ & 22 & 401 & 39.9 & 46 & 4.8 & 55.2 & 39.9 \\
\hline Feed-to-gain ratio, g/g & 21 & 2.699 & 97.7 & 0.388 & 0.6 & 71.7 & 27.8 \\
\hline Feed intake, $\mathrm{g} / \mathrm{d}$ & 21 & 236 & 98.7 & 23 & 2.3 & 66.9 & 30.8 \\
\hline
\end{tabular}

\footnotetext{
${ }^{1}$ Male $=$ Nicholas 700 (Aviagen Turkeys Ltd., Tattenhall, Cheshire, UK), and female = Hybrid Converter (Hybrid Turkeys, Kitchener, Ontario,
} Canada). 


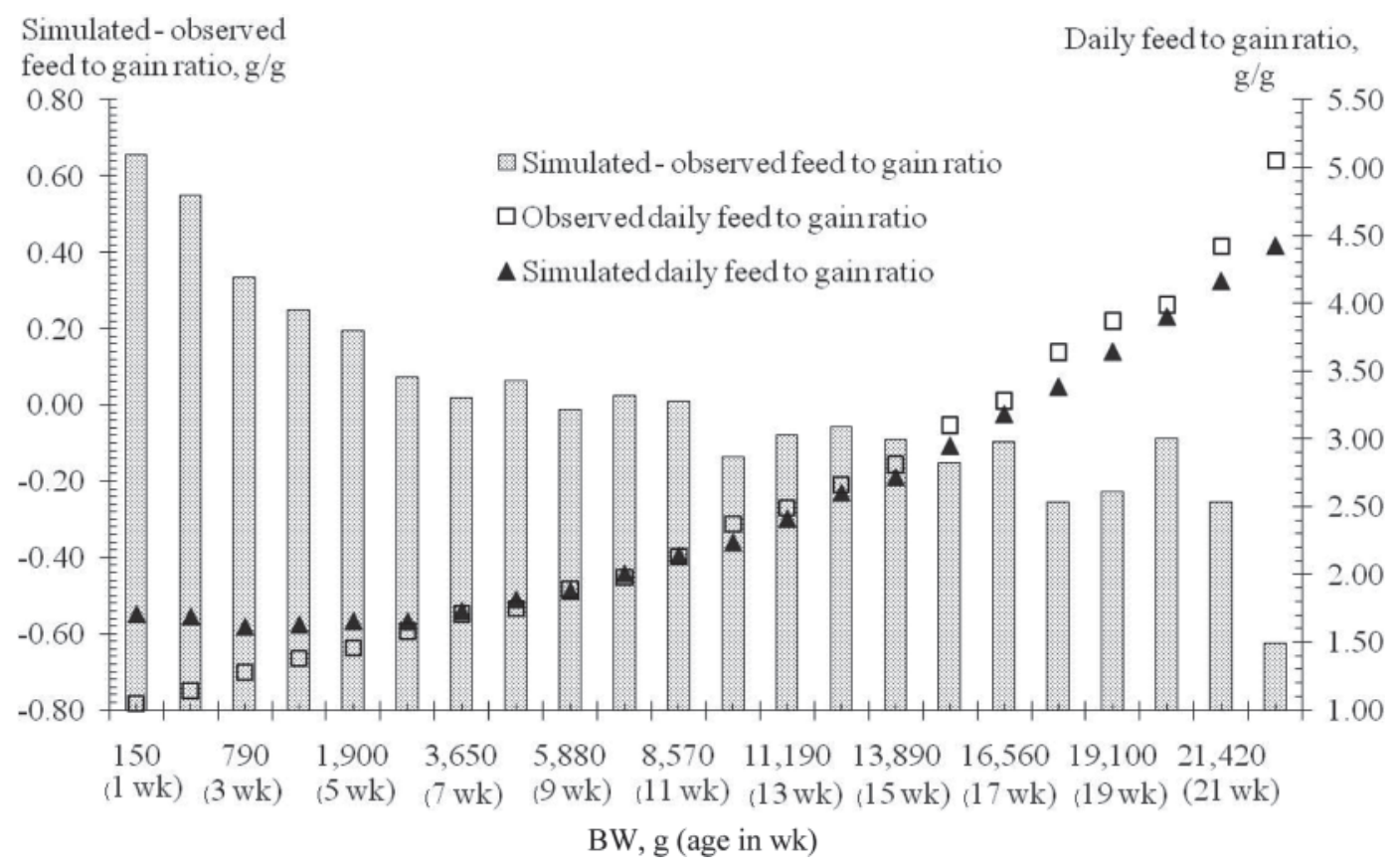

Figure 6. Comparison between simulated and observed daily feed-to-gain ratio in a male genotype (Nicholas 700, Aviagen Turkeys Ltd., Tattenhall, Cheshire, UK) and evolution of the error of simulation (simulated - observed values, g/g) of daily feed-to-gain ratio (vertical bars) with BW from 1 to $21 \mathrm{wk}$ of age. The relative error of simulation was calculated as the relative difference between the simulated and the observed values.

adaptive response of the turkey individual was assumed to be due to both external and endogenous rules. The interday HS regulations relied on the hypothesis that the growth trajectory results from complex interactions between genotype and ambient conditions (Bodin et al., 2010). Thus, it is not only homeorhesis that drives the growth trajectory. The adjustment of the 6 parameters of the interday HS regulations enabled the adaptation of the growth trajectory to different genotypes characterized by the observed data on BW gain, feed

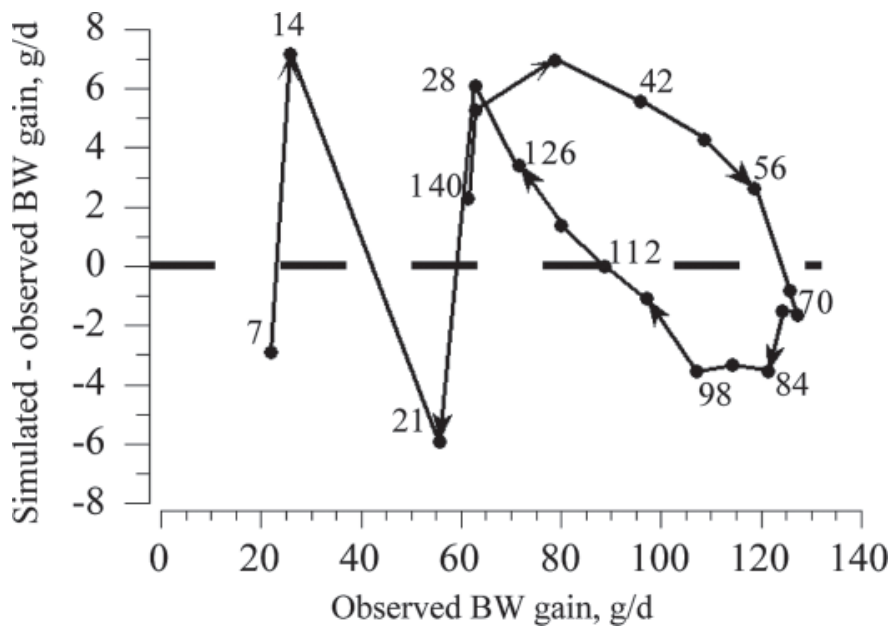

Figure 7. Difference between simulated and observed daily BW gain in a female genotype of turkeys (Hybrid Converter, Hybrid Turkeys, Kitchener, Ontario, Canada) as a function of the observed values; the corresponding age is mentioned in the graph and junctions between points are made following increasing ages. The average error of simulation is $1.0 \mathrm{~g} / \mathrm{d}$. intake, and feed-to-gain ratio during growth. Based on this fairly simple adjustment to BW gain, feed intake, and feed-to-gain ratio, the model may be fairly easy applicable to commercial facilities.

The energy and $\mathrm{N}$ balances measured experimentally (Rivera-Torres et al., 2010b, 2011a) and the serial slaughter analyses (Rivera-Torres et al., 2011b) provided datasets that enabled us to calibrate the parameters at different levels of organization of the teleonomic system (i.e., from feed intake to daily $\mathrm{CO}_{2}$ production and ash retention in feathers). The energy and $\mathrm{N}$ balances provided quantitative information to calibrate the in-

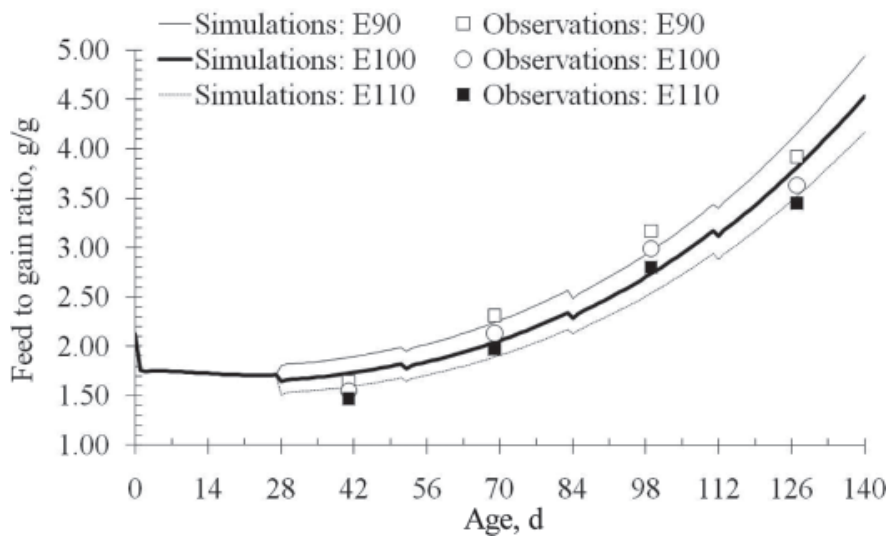

Figure 8. Model simulation of the turkey response to different energy (E) content (90 vs. $110 \%$ of the control treatment); comparison between simulated and observed (Veldkamp et al., 2005) values. The E90 and E110 refer to an energy content of 90 and 110\%, respectively, of the control treatment. The E90 and E110 observations are the values determined by Veldkamp et al. (2005). 
traday HS regulations associated with nutrient utilization for retention or $\mathrm{AA}, \mathrm{Gl}$, and $\mathrm{FA}$ oxidation into $\mathrm{CO}_{2}$, whereas the serial slaughter analyses enabled to define the contribution of carcass, viscera, and feathers in whole BW gain. Because of the lack of information on body composition of female turkeys, the results from the serial slaughter analyses were used as a basis for the definition of the growth dynamics of protein and lipid retention in carcass, viscera, and feathers, and the parameters associated with protein and lipid turnovers in viscera were assumed similar between sexes. However, more information on the evolution of the body composition of females during growth may be useful to validate this hypothesis.

Along with protein and lipid turnover in carcass and viscera, the differences in body composition between male and female turkeys were due to the allometric relation between water and protein. Gous et al. (1999) observed a statistically significant effect of sex and strain on the allometric relation of water with protein. In this study, we used the parameter estimates of a previous study (Rivera-Torres et al., 2011b) and those of Emmans (1989) to define the allometric relation of water with protein in male and female turkeys (i.e., 2.90 Prot and 3.41 Prot $^{0.90}$, respectively, where Prot equals the mass of carcass or viscera protein). The results of the simulations in females showed that the allometric relation of water with protein may be appropriate for females because both BW gain and protein and lipid retention were in accordance with observations. However, this observation was not true for male turkeys. Because water is the major constituent in daily BW gain, it is possible that the allometric relation of water with protein was the origin of the error in the simulation of BW gain at early and later ages because BW gain was globally overestimated, in spite of an accurate simulation of protein retention and an underestimation of lipid retention.

Contrary to other growth models (King, 2001; Eits et al., 2003), the version of the model described herein does not account for the effect of temperature and individual AA on the growth response. The effect of temperature is an important factor to consider in a model for simulating commercial conditions because heat stress is known to have a negative effect on feed intake. Also, Hurwitz and Bengal (1982) demonstrated that basal energy metabolism in turkeys can be defined as a function of ambient temperature. The model represents total AA as a single AA pool. Although such a development would increase the number of circulating compartments in the model, it would enable to propose AA recommendations while accounting for the changes in basal metabolism (i.e., basal protein turnover) and nutrient utilization (i.e., endogenous losses and AA oxidation) with genotype and nutrition.

The user should keep in mind that the model simulates average growth responses rather than individual ones. Indeed, the average growth profile of a population may differ from that of the average individual within that same population (Pomar et al., 2003). The adaptability of the model to different genotypes and growing conditions, and its ability to simulate the effect of nutrition on growth performance, represent a step toward a better knowledge of turkey growth dynamics and net nutrient recommendations.

\section{LITERATURE CITED}

Adedokun, S. A., O. Adeola, C. M. Parsons, M. S. Lilburn, and T. J. Applegate. 2007a. Methodology for endogenous flow estimates for standardization of digestible amino acids. J. Anim. Sci. 85:395. (Abstr.)

Adedokun, S. A., M. S. Lilburn, C. M. Parsons, O. Adeola, and T. J. Applegate. 2007b. Effect of age and method on ileal endogenous amino acid flow in turkey poults. Poult. Sci. 86:1948-1954.

Aimiuwu, O. C., and M. S. Lilburn. 2008. The effects of varying levels of digestible lysine on growth and carcass development in commercial turkey toms from 12 to 16 and 17 to 20 weeks. Poult. Sci. 87:9-10.

Baldwin, R. L., N. E. Smith, J. Taylor, and M. Sharp. 1980. Manipulating metabolic parameters to improve growth-rate and milk secretion. J. Anim. Sci. 51:1416-1428.

Bodin, L., G. Bolet, M. Garcia, H. Garreau, C. Larzul, and I. David. 2010. Canalisation and robustness: the geneticist insight. INRA Prod. Anim. 23:11-21.

Buffington, D. E., K. A. Jordan, L. L. Boyd, and W. A. Junnila. 1973. Mathematical-models of growth data of male and female Wrolstad White turkeys. Poult. Sci. 52:1694-1700.

Campbell, N. A., and J. B. Reece. 2005. Biology. 7th ed. Pearson Education, Upper Saddle River, NJ.

Chwalibog, A., and G. Thorbek. 1999. Nutrient oxidation and lipogenesis in hens. J. Anim. Physiol. Anim. Nutr. (Berl.) 82:282293.

Collin, A., R. D. Malheiros, V. M. Moraes, P. Van As, V. M. Darras, M. Taouis, E. Decuypere, and J. Buyse. 2003. Effects of dietary macronutrient content on energy metabolism and uncoupling protein mRNA expression in broiler chickens. Br. J. Nutr. 90:261-269.

Danfaer, A. 1991. Mathematical modeling of metabolic regulation and growth. Livest. Prod. Sci. 27:1-18.

Eits, R. M., R. P. Kwakkel, and M. W. A. Verstegen. 2002. Nutrition affects fat-free body composition in broiler chickens. J. Nutr. 132:2222-2228.

Eits, R. M., R. P. Kwakkel, M. W. A. Verstegen, and G. C. Emmans. 2003. Responses of broiler chickens to dietary protein: Effects of early life protein nutrition on later responses. Br. Poult. Sci. 44:398-409.

Emmans, G. C. 1987. Growth, body composition and feed intake. World's Poult. Sci. J. 43:208-227.

Emmans, G. C. 1989. The growth of turkeys. Recent advances in turkey science. Poult. Sci. Symp. 21:135-166.

Firman, J. D. 1994. Turkey growth modelling: Metabolic approach. J. Appl. Poult. Res. 3:373-378.

Firman, J. D., and S. D. Boling. 1998. Ideal protein in turkeys. Poult. Sci. 77:105-110.

Foglia, T. A., A. L. Cartwright, R. J. Gyurik, and J. G. Philips. 1994. Fatty acid turnover rates in the adipose tissues of the growing chicken (Gallus domesticus). Lipids 29:497-502.

Geraert, P. A., B. Leclercq, and M. Larbier. 1987. Effects of dietary glucogenic amino-acid supplementation on growth performance, body composition and plasma free amino-acid levels in genetically lean and fat chickens. Reprod. Nutr. Dev. 27:1041-1051.

Gerrits, W. J. J., J. Dijkstra, and J. France. 1997. Description of a model integrating protein and energy metabolism in preruminant calves. J. Nutr. 127:1229-1242.

Gill, M., J. France, M. Summers, B. W. McBride, and L. P. Milligan. 1989. Simulation of the energy costs associated with protein 
turnover and $\mathrm{Na}^{+}, \mathrm{K}^{+}$transport in growing lambs. J. Nutr. 119:1287-1299.

Gous, R. M., E. T. Moran, H. R. Stilborn, G. D. Bradford, and G. Emmans. 1999. Evaluation of the parameters needed to describe the overall growth, the chemical growth, and the growth of feathers and breast muscles of broilers. Poult. Sci. 78:812821.

Honda, K., H. Kamisoyama, Y. Isshiki, and S. Hasegawa. 2009. Effects of dietary fat levels on nutrient digestibility at different sites of chicken intestines. Jpn. Poult. Sci. 46:291-295.

Hurwitz, S., and I. Bengal. 1982. Energy use and performance of young turkeys kept under various constant and cycling environmental temperatures. Poult. Sci. 61:1082-1086.

Hurwitz, S., Y. Frisch, A. Bar, U. Eisner, I. Bengal, and M. Pines. 1983. The amino acid requirements of growing turkeys. 1. Model construction and parameter estimation. Poult. Sci. 62:22082217.

Hurwitz, S., H. Talpaz, I. Bartov, and I. Plavnik. 1991. Characterization of growth and development of male British united turkeys. Poult. Sci. 70:2419-2424.

Jones, S. J., M. D. Judge, and E. D. Aberle. 1986. Muscle protein turnover in sex-linked dwarf and normal broiler chickens. Poult. Sci. 65:2082-2089.

Kang, C. W., M. L. Sunde, and R. W. Swick. 1985a. Characteristics of growth and protein turnover in skeletal muscle of turkey poults. Poult. Sci. 64:380-387.

Kang, C. W., M. L. Sunde, and R. W. Swick. 1985b. Growth and protein turnover in the skeletal muscles of broiler chicks. Poult. Sci. 64:370-379.

King, R. D. 2001. Description of a growth simulation model for predicting the effect of diet on broiler composition and growth. Poult. Sci. 80:245-253.

Lemarchal, P., P. Beaunez, C. Roger, and P. Legrand. 1988. In vivo turnover of triglyceride fatty-acids in adipose tissue of chickens (Gallus domesticus) selected for low or high adiposity. Comp. Biochem. Physiol. 89B:227-231.

Lovatto, P. A., and D. Sauvant. 2003. Modeling homeorhetic and homeostatic controls of pig growth. J. Anim. Sci. 81:683-696.

McCartney, M. 1952. Total blood and corpuscular volume in turkey hens. Poult. Sci. 31:184-185.

Morgan, J. B., S. J. Jones, and C. R. Calkins. 1989. Muscle proteinturnover and tenderness in broiler-chickens fed cimaterol. J. Anim. Sci. 67:2646-2654.

Muramatsu, T., and J. Okumura. 1985. Whole-body protein-turnover in chicks at early stages of growth. J. Nutr. 115:483-490.

NRC. 1994. Nutrient Requirements for Poultry. 9th rev. ed. Natl. Acad. Press, Washington, DC.

Oviedo-Rondon, E. O., and P. W. Waldroup. 2002. Models to estimate amino acid requirements for broiler chickens: A review. Int. J. Poult. Sci. 1:106-113.

Pomar, C., I. Kyriazakis, G. Emmans, and P. W. Knap. 2003. Modeling stochasticity: Dealing with populations rather than individual pigs. J. Anim. Sci. 81:E178-E186.

Pym, R. A. E., B. Leclercq, F. M. Tomas, and S. Tesseraud. 2004. Protein utilisation and turnover in lines of chickens selected for different aspects of body composition. Br. Poult. Sci. 45:775786 .

Rivera-Torres, V., P. Ferket, and D. Sauvant. 2010a. Model development of nutrient utilization to represent poultry growth dynamics: Application to the turkey. Pages 291-298 in Modelling Nutrient digestion and utilization in farm animals. D. Sauvant, J. van Milgen, P. Faverdin, and N. Friggens, ed. Wageningen Academic Publishers, Wageningen, the Netherlands.
Rivera-Torres, V., J. Noblet, S. Dubois, and J. van Milgen. 2010b. Energy partitioning in male growing turkeys. Poult. Sci. $89: 530-538$

Rivera-Torres, V., J. Noblet, S. Dubois, and J. van Milgen. 2011a. Dynamics of energy utilization in male and female turkeys during growth. Animal 5:202-210.

Rivera-Torres, V., J. Noblet, and J. van Milgen. 2011b. Changes in chemical body composition of male turkeys during growth. Poult. Sci. 90:68-74.

Sato, T., S. Soeda, Y. Ohta, K. Katayama, T. Arai, and H. Tazaki. 2008. Plasma glucose, mannose, and non-esterified fatty acid concentrations in layer-type chickens. Br. Poult. Sci. 49:731735 .

Sauvant, D. 1992. Systemic modeling in nutrition. Reprod. Nutr. Dev. 32:217-230.

Sauvant, D., J. M. Perez, and G. Tran. 2004. Tables of composition and nutritional value of feed materials: Pigs, poultry, cattle, sheep, goats, rabbits, horses and fish. INRA, Paris, France.

Strathe, A. B., A. Danfaer, and A. Chwalibog. 2008. A dynamic model of digestion and absorption in pigs. Anim. Feed Sci. Technol. 143:328-371.

Tedeschi, L. O. 2006. Assessment of the adequacy of mathematical models. Agric. Syst. 89:225-247.

Tesseraud, S., A. M. Chagneau, and J. Grizard. 2000. Muscle protein turnover during early development in chickens divergently selected for growth rate. Poult. Sci. 79:1465-1471.

Tesseraud, S., M. Larbier, A. M. Chagneau, and P. A. Geraert. 1992. Effect of dietary lysine on muscle protein-turnover in growing chickens. Reprod. Nutr. Dev. 32:163-171.

Tesseraud, S., N. Maaa, R. Peresson, and A. M. Chagneau. 1996a. Relative responses of protein turnover in three different skeletal muscles to dietary lysine deficiency in chicks. Br. Poult. Sci. $37: 641-650$.

Tesseraud, S., R. Peresson, and A. M. Chagneau. 1996b. Age-related changes of protein turnover in specific tissues of the chick. Poult. Sci. 75:627-631.

Tesseraud, S., R. Peresson, J. Lopes, and A. M. Chagneau. 1996c. Dietary lysine deficiency greatly affects muscle and liver protein turnover in growing chickens. Br. J. Nutr. 75:853-865.

Tesseraud, S., S. Temim, E. Le Bihan-Duval, and A. M. Chagneau. 2001. Increased responsiveness to dietary lysine deficiency of pectoralis major muscle protein turnover in broilers selected on breast development. J. Anim. Sci. 79:927-933.

Tomas, F. M., R. A. Pym, and R. J. Johnson. 1991. Muscle proteinturnover in chickens selected for increased growth-rate, foodconsumption or efficiency of food utilization-Effects of genotype and relationship to plasma IGF-I and growth-hormone. Br. Poult. Sci. 32:363-376.

Urdaneta-Rincon, M., and S. Leeson. 2004. Muscle (pectoralis major) protein turnover in young broiler chickens fed graded levels of lysine and crude protein. Poult. Sci. 83:1897-1903.

van Milgen, J. 2002. Modeling biochemical aspects of energy metabolism in mammals. J. Nutr. 132:3195-3202.

Veldkamp, T., R. P. Kwakkel, P. R. Ferket, and M. W. A. Verstegen. 2005. Growth responses to dietary energy and lysine at high and low ambient temperature in male turkeys. Poult. Sci. 84:273-282.

Vitezica, Z. G., C. Marie-Etancelin, M. D. Bernadet, X. Fernandez, and C. Robert-Granie. 2010. Comparison of nonlinear and spline regression models for describing mule duck growth curves. Poult. Sci. 89:1778-1784. 


\section{APPENDIX}

Table A1. Mathematical statement of the turkey growth model ${ }^{1}$

\begin{tabular}{|c|c|c|}
\hline Description & Equation & No. \\
\hline \multicolumn{3}{|l|}{ Carcass } \\
\hline Input & $\mathrm{F}_{\mathrm{AA}, \mathrm{Pc} / \mathrm{Pc}}(\mathrm{t})=\mathrm{k}_{\mathrm{s}}+\mathrm{A}_{\mathrm{iPc}} \exp \left(-\mathrm{A}_{\mathrm{ePc}} \mathrm{t}\right) \exp \left\{\mathrm{Ve}_{\mathrm{PT}}\left[\Delta \mathrm{C}_{\mathrm{AA}}(\mathrm{t})\right]\right\} \mathrm{P}_{\mathrm{C}}(\mathrm{t})$ & 1.1 \\
\hline Output & $\mathrm{F}_{\mathrm{Pc}, \mathrm{AA} / \mathrm{Pc}}(\mathrm{t})=\mathrm{k}_{\mathrm{s}}+\mathrm{C}_{\mathrm{iPc}} \exp \left(-\mathrm{C}_{\mathrm{ePc}} \mathrm{t}\right) \exp \left\{-\mathrm{Ve}_{\mathrm{PT}}\left[\Delta \mathrm{C}_{\mathrm{AA}}(\mathrm{t})\right]\right\} \mathrm{P}_{\mathrm{C}}(\mathrm{t})$ & 1.2 \\
\hline Differential equation & $\mathrm{dP}_{\mathrm{c}} / \mathrm{dt}=\mathrm{F}_{\mathrm{AA}, \mathrm{Pc} / \mathrm{Pc}}(\mathrm{t})-\mathrm{F}_{\mathrm{Pc}, \mathrm{AA} / \mathrm{Pc} \mathrm{t}}(\mathrm{t})$ & 1.3 \\
\hline Output & $\mathrm{F}_{\mathrm{Lc}, \mathrm{FA}-\mathrm{Gl} / \mathrm{Lc}}(\mathrm{t})=\mathrm{k}_{\mathrm{s}}+\mathrm{C}_{\mathrm{iLc}} \exp \left(-\mathrm{C}_{\mathrm{eLc}} \mathrm{t}\right) \exp \left\{-\mathrm{Ve}_{\mathrm{LT}}\left[\Delta \mathrm{C}_{\mathrm{FA}}(\mathrm{t})\right]\right\} \exp \left\{-\mathrm{VeGl}\left[\Delta \mathrm{C}_{\mathrm{FA}}(\mathrm{t})\right]\right\} \mathrm{L}_{\mathrm{C}}(\mathrm{t})$ & 1.5 \\
\hline Differential equation & $\mathrm{dL}_{\mathrm{c}} / \mathrm{dt}=\mathrm{F}_{\mathrm{FA}-\mathrm{Gl}, \mathrm{Lc} / \mathrm{FA}}(\mathrm{t})-\mathrm{F}_{\mathrm{Lc}, \mathrm{FA}-\mathrm{Gl} / \mathrm{Lc}}(\mathrm{t})$ & 1.6 \\
\hline \multicolumn{3}{|l|}{$\operatorname{Ash}\left(A_{c}\right), g$} \\
\hline Input & $\mathrm{FA}_{\mathrm{c}}=\mathrm{a}_{\mathrm{PCV}}\left[\mathrm{F}_{\mathrm{AA}, \mathrm{Pc} / \mathrm{Pc}}(\mathrm{t})-\mathrm{F}_{\mathrm{Pc}, \mathrm{AA} / \mathrm{Pc}}(\mathrm{t})\right]$ & 1.7 \\
\hline Differential equation & $\mathrm{dA}_{\mathrm{c}} / \mathrm{dt}=\mathrm{FA}_{\mathrm{c}}$ & 1.8 \\
\hline \multicolumn{3}{|l|}{ Water $\left(\mathrm{W}_{\mathrm{c}}\right), \mathrm{g}$} \\
\hline Output & $\mathrm{F}_{\mathrm{Pv}, \mathrm{AA} / \mathrm{Pv}}(\mathrm{t})=\mathrm{k}_{\mathrm{s}}+\mathrm{C}_{\mathrm{iPv}} \exp \left(-\mathrm{C}_{\mathrm{ePv}} \mathrm{t}\right) \exp \left\{-\mathrm{Ve}_{\mathrm{PT}}\left[\Delta \mathrm{C}_{\mathrm{AA}}(\mathrm{t})\right]\right\} \mathrm{P}_{\mathrm{V}}(\mathrm{t})$ & 2.2 \\
\hline Differential equation & $\mathrm{dP}_{\mathrm{v}} / \mathrm{dt}=\mathrm{F}_{\mathrm{AA}, \mathrm{P}_{\mathrm{v}} / \mathrm{P}_{\mathrm{v}}}(\mathrm{t})-\mathrm{F}_{\mathrm{Pv}_{\mathrm{v}, \mathrm{AA} / \mathrm{P}_{\mathrm{v}}}}(\mathrm{t})$ & 2.3 \\
\hline \multicolumn{3}{|l|}{ Lipid $\left(\mathrm{L}_{\mathrm{v}}\right), \mathrm{g}$} \\
\hline Input & $\mathrm{F}_{\mathrm{FA}-\mathrm{Gl}, \mathrm{Lv} / \mathrm{FA}}(\mathrm{t})=\mathrm{k}_{\mathrm{s}}+\mathrm{A}_{\mathrm{iLv}} \exp \left(-\mathrm{A}_{\mathrm{eLv}} \mathrm{t}\right) \exp \left\{\mathrm{Ve}_{\mathrm{LT}}\left[\Delta \mathrm{C}_{\mathrm{FA}}(\mathrm{t})\right]\right\} \exp \left\{\mathrm{VeGl}\left[\Delta \mathrm{C}_{\mathrm{FA}}(\mathrm{t})\right]\right\} \mathrm{L}_{\mathrm{V}}(\mathrm{t})$ & 2.4 \\
\hline Output & $\mathrm{F}_{\mathrm{Lv}, \mathrm{FA}-\mathrm{Gl} / \mathrm{Lv}}(\mathrm{t})=\mathrm{k}_{\mathrm{s}}+\mathrm{C}_{\mathrm{iLv}} \exp \left(-\mathrm{C}_{\mathrm{eLv}} \mathrm{t}\right) \exp \left\{-\mathrm{Ve}_{\mathrm{LT}}\left[\Delta \mathrm{C}_{\mathrm{FA}}(\mathrm{t})\right]\right\} \exp \left\{-\mathrm{VeGl}\left[\Delta \mathrm{C}_{\mathrm{FA}}(\mathrm{t})\right]\right\} \mathrm{L}_{\mathrm{V}}(\mathrm{t})$ & 2.5 \\
\hline Differential equation & $\mathrm{dL}_{\mathrm{v}} / \mathrm{dt}=\mathrm{F}_{\mathrm{FA}-\mathrm{Gl}, \mathrm{Lv} / \mathrm{FA}}(\mathrm{t})-\mathrm{F}_{\mathrm{Lv}, \mathrm{FA}-\mathrm{Gl} / \mathrm{Lv}}(\mathrm{t})$ & 2.6 \\
\hline \multicolumn{3}{|l|}{ Ash $\left(A_{v}\right), g$} \\
\hline Input & 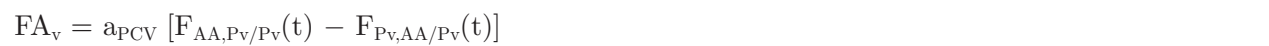 & 2.7 \\
\hline Differential equation & $\mathrm{dA}_{\mathrm{v}} / \mathrm{dt}=\mathrm{FA}_{\mathrm{v}}$ & 2.8 \\
\hline \multicolumn{3}{|l|}{ Water $\left(W_{v}\right), g$} \\
\hline Input & $\mathrm{FW}_{\mathrm{v}}=\mathrm{a}_{\mathrm{W}}\left[\mathrm{F}_{\mathrm{AA}, \mathrm{Pv}_{\mathrm{v}} / \mathrm{Pv}_{\mathrm{v}}}(\mathrm{t})-\mathrm{F}_{\mathrm{Pv}, \mathrm{AA} / \mathrm{Pv}_{\mathrm{v}}}(\mathrm{t})\right]$ & 2.9 \\
\hline Differential equation & $\mathrm{dW}_{\mathrm{v}} / \mathrm{dt}=\mathrm{FW}_{\mathrm{v}}$ & 2.10 \\
\hline Input & $\mathrm{FW}_{\mathrm{f}}=\mathrm{w}_{\mathrm{Pf}} \mathrm{F}_{\mathrm{AA}, \mathrm{Pf} / \mathrm{Pf}}(\mathrm{t})$ & 3.5 \\
\hline Differential equation & $\mathrm{dW}_{\mathrm{f}} / \mathrm{dt}=\mathrm{FW}_{\mathrm{f}}$ & 3.6 \\
\hline \multicolumn{3}{|l|}{ Summative equations } \\
\hline Carcass $(\mathrm{C}), \mathrm{g}$ & $\mathrm{C}(\mathrm{t})=\mathrm{A}_{\mathrm{c}}(\mathrm{t})+\mathrm{W}_{\mathrm{c}}(\mathrm{t})+\mathrm{P}_{\mathrm{c}}(\mathrm{t})+\mathrm{L}_{\mathrm{c}}(\mathrm{t})$ & 3.7 \\
\hline Viscera $(\mathrm{V}), \mathrm{g}$ & $\mathrm{C}(\mathrm{t})=\mathrm{A}_{\mathrm{v}}(\mathrm{t})+\mathrm{W}_{\mathrm{v}}(\mathrm{t})+\mathrm{P}_{\mathrm{v}}(\mathrm{t})+\mathrm{L}_{\mathrm{v}}(\mathrm{t})$ & 3.8 \\
\hline Feathers $(\mathrm{F}), \mathrm{g}$ & $\mathrm{F}(\mathrm{t})=\mathrm{A}_{\mathrm{f}}(\mathrm{t})+\mathrm{W}_{\mathrm{f}}(\mathrm{t})+\mathrm{P}_{\mathrm{f}}(\mathrm{t})$ & 3.9 \\
\hline $\mathrm{BW}, \mathrm{g}$ & $\mathrm{BW}(\mathrm{t})=\mathrm{A}_{\mathrm{c}}(\mathrm{t})+\mathrm{W}_{\mathrm{c}}(\mathrm{t})+\mathrm{P}_{\mathrm{c}}(\mathrm{t})+\mathrm{L}_{\mathrm{c}}(\mathrm{t})+\mathrm{A}_{\mathrm{v}}(\mathrm{t})+\mathrm{W}_{\mathrm{v}}(\mathrm{t})+\mathrm{P}_{\mathrm{v}}(\mathrm{t})+\mathrm{L}_{\mathrm{v}}(\mathrm{t})+\mathrm{A}_{\mathrm{f}}(\mathrm{t})+\mathrm{W}_{\mathrm{f}}(\mathrm{t})+\mathrm{P}_{\mathrm{f}}(\mathrm{t})$ & 3.10 \\
\hline Circulating compartment & & \\
\hline $\mathrm{AA}, \mathrm{g}$ & & \\
\hline Concentration & $\mathrm{C}_{\mathrm{AA}}(\mathrm{t})=\mathrm{AA}(\mathrm{t}) /[\mathrm{Bv} \operatorname{PoB} \mathrm{BW}(\mathrm{t})]$ & 4.1 \\
\hline Inputs & $\mathrm{F}_{\mathrm{Pc}, \mathrm{AA} / \mathrm{AA}}(\mathrm{t})+\mathrm{F}_{\mathrm{PV}, \mathrm{AA} / \mathrm{AA}}(\mathrm{t})+$ FeedCPi FI $(\mathrm{t}) \mathrm{SID}_{\mathrm{AA}}$ & 4.2 \\
\hline Outputs & $\mathrm{F}_{\mathrm{AA}, \mathrm{Pc} / \mathrm{AA}}(\mathrm{t})+\mathrm{F}_{\mathrm{AA}, \mathrm{Pv} / \mathrm{AA}}(\mathrm{t})+\mathrm{F}_{\mathrm{AA}, \mathrm{Pf} / \mathrm{AA}}(\mathrm{t})+\mathrm{F}_{\mathrm{AA}, \mathrm{Gl} / \mathrm{AA}}(\mathrm{t})+\mathrm{F}_{\mathrm{AA}, \mathrm{Av} / \mathrm{AA}}(\mathrm{t})+\operatorname{IEAA}(\mathrm{t})$ & 4.3 \\
\hline Differential equation & & \\
\hline Auxiliary equations & $\mathrm{F}_{\mathrm{AA}, \mathrm{Gl} / \mathrm{AA}}=\mathrm{k}_{\mathrm{ox}} \mathrm{AA}(\mathrm{t}) \exp \left\{\mathrm{Ve}_{\mathrm{AAox}}\left[\Delta \mathrm{C}_{\mathrm{AA}}(\mathrm{t})\right]\right\} \exp \left\{-\mathrm{Ve}_{\mathrm{Gl}}\left[\Delta \mathrm{C}_{\mathrm{Gl}}(\mathrm{t})\right]\right\}$ & 4.4 \\
\hline & $\mathrm{F}_{\mathrm{AA}, \mathrm{Ay} / \mathrm{AA}}(\mathrm{t})=\mathrm{k}_{\mathrm{ox}} \mathrm{AA}(\mathrm{t}) \exp \left\{\mathrm{Ve}_{\mathrm{AAox}}\left[\Delta \mathrm{C}_{\mathrm{AA}}(\mathrm{t})\right]\right\}-\mathrm{F}_{\mathrm{AA}, \mathrm{Gl} / \mathrm{AA}}$ & 4.5 \\
\hline & $\operatorname{IEAA}(\mathrm{t})=\mathrm{a}_{\mathrm{IEAA}} \mathrm{DM}_{\text {intake }} / 1000$ & 4.6 \\
\hline & $\mathrm{FI}(\mathrm{t})=\mathrm{MEI}(\mathrm{t}) /$ feedMEi & 4.7 \\
\hline & $\operatorname{MEI}(\mathrm{t})=\left[\mathrm{a}_{\mathrm{MEm}}+\mathrm{d}_{\mathrm{MEm}} \mathrm{BW}(\mathrm{t})\right] \mathrm{BW}(\mathrm{t})^{0.75}+1 / \mathrm{k}_{\mathrm{p}} \operatorname{REP}(\mathrm{t})+1 / \mathrm{k}_{\mathrm{f}} \operatorname{REL}(\mathrm{t})$ & 4.8 \\
\hline & $\mathrm{REP}(\mathrm{t})=\left[\mathrm{F}_{\mathrm{AA}, \mathrm{Pc} / \mathrm{Pc}}(\mathrm{t})-\mathrm{F}_{\mathrm{Pc}, \mathrm{AA} / \mathrm{Pc}}(\mathrm{t})+\mathrm{F}_{\mathrm{AA}, \mathrm{Pv} / \mathrm{Pv}_{\mathrm{Pv}}}(\mathrm{t})-\mathrm{F}_{\mathrm{Pv}, \mathrm{AA} / \mathrm{Pv}}(\mathrm{t})+\mathrm{F}_{\mathrm{AA}, \mathrm{Pf} / \mathrm{Pf}}(\mathrm{t})\right] \mathrm{E}_{\mathrm{P}}$ & 4.9 \\
\hline & $\operatorname{REL}(\mathrm{t})=\left[\mathrm{F}_{\mathrm{FA}-\mathrm{Gl} / \mathrm{Lc} / \mathrm{Lc}}(\mathrm{t})-\mathrm{F}_{\mathrm{Lc}, \mathrm{FA}-\mathrm{Gl} / \mathrm{Lc}}(\mathrm{t})+\mathrm{F}_{\mathrm{FA}-\mathrm{Gl}, \mathrm{Lv} / \mathrm{Lv}}(\mathrm{t})-\mathrm{F}_{\mathrm{Lv}, \mathrm{FA}-\mathrm{Gl} / \mathrm{Lv} v}(\mathrm{t})\right] \mathrm{E}_{\mathrm{L}}$ & 4.10 \\
\hline & $\mathrm{DM}_{\text {intake }}(\mathrm{t})=\mathrm{FI}(\mathrm{t})$ feedDM & 4.11 \\
\hline Glucose $(\mathrm{Gl}), \mathrm{g}$ & & \\
\hline Concentration & $\mathrm{C}_{\mathrm{Gl}}(\mathrm{t})=\mathrm{Gl}(\mathrm{t}) /[\mathrm{Bv} \operatorname{PoB} \mathrm{BW}(\mathrm{t})]$ & 5.1 \\
\hline Inputs & $\mathrm{F}_{\mathrm{AA}, \mathrm{Gl} / \mathrm{Gl}}(\mathrm{t})+\mathrm{F}_{\mathrm{Lc}, \mathrm{Gl} / \mathrm{Gl}}(\mathrm{t})+\mathrm{F}_{\mathrm{Lv}, \mathrm{Gl} / \mathrm{Gl}}(\mathrm{t})+\mathrm{Gl}_{\text {intake }}$ & 5.2 \\
\hline
\end{tabular}


Table A1 (Continued). Mathematical statement of the turkey growth model ${ }^{1}$

\begin{tabular}{|c|c|c|}
\hline Outputs & $\mathrm{F}_{\mathrm{Gl}, \mathrm{Lc} / \mathrm{Gl}}(\mathrm{t})+\mathrm{F}_{\mathrm{Gl}, \mathrm{Lv} / \mathrm{Gl}}(\mathrm{t})+\mathrm{F}_{\mathrm{Gl}, \mathrm{Ay} / \mathrm{Gl}}(\mathrm{t})$ & 5.3 \\
\hline Differential equation & $\mathrm{dGl} / \mathrm{dt}=\mathrm{F}_{\mathrm{AA}, \mathrm{Gl} / \mathrm{Gl}}(\mathrm{t})+\mathrm{F}_{\mathrm{Lc}, \mathrm{Gl} / \mathrm{Gl}}(\mathrm{t})+\mathrm{F}_{\mathrm{Lv}, \mathrm{Gl} / \mathrm{Gl}}(\mathrm{t})+\mathrm{Gl}_{\text {intake }}-\mathrm{F}_{\mathrm{Gl}, \mathrm{Lc} / \mathrm{Gl}}(\mathrm{t})-\mathrm{F}_{\mathrm{Gl}, \mathrm{Lv} / \mathrm{Gl}}(\mathrm{t})-\mathrm{F}_{\mathrm{Gl}, \mathrm{Ay} / \mathrm{Gl}}(\mathrm{t})$ & 5.4 \\
\hline & $\mathrm{F}_{\mathrm{Gl}, \mathrm{Ay} / \mathrm{Gl}}(\mathrm{t})=\mathrm{k}_{\mathrm{ox}} \mathrm{Gl}(\mathrm{t}) \exp \left\{\operatorname{Ve}_{\mathrm{Glox}}\left[\Delta \mathrm{C}_{\mathrm{Gl}}(\mathrm{t})\right]\right\}$ & 5.6 \\
\hline Fatty acid (FA), g & & \\
\hline Concentration & $\mathrm{C}_{\mathrm{FA}}(\mathrm{t})=\mathrm{FA}(\mathrm{t}) /[\mathrm{Bv} \mathrm{PoB} \mathrm{BW}(\mathrm{t})]$ & 6.1 \\
\hline \multirow[t]{2}{*}{ Differential equation } & $\mathrm{dFA} / \mathrm{dt}=\mathrm{F}_{\mathrm{Ay}, \mathrm{FA} / \mathrm{FA}}(\mathrm{t})+\mathrm{F}_{\mathrm{Lc}, \mathrm{FA} / \mathrm{FA}}(\mathrm{t})+\mathrm{F}_{\mathrm{Lv}, \mathrm{FA} / \mathrm{FA}}(\mathrm{t})+\mathrm{CF}_{\text {intake }}-\mathrm{F}_{\mathrm{FA}, \mathrm{Ay} / \mathrm{FA}}(\mathrm{t})-$ & 6.4 \\
\hline & $\mathrm{F}_{\mathrm{FA}, \mathrm{Lc} / \mathrm{FA}}(\mathrm{t})-\mathrm{F}_{\mathrm{FA}, \mathrm{Lv} / \mathrm{FA}}(\mathrm{t})$ & 6.5 \\
\hline \multirow[t]{3}{*}{ Auxiliary equation } & $\mathrm{CF}_{\text {intake }}(\mathrm{t})=$ FeedCFi FI $(\mathrm{t})$ & 6.6 \\
\hline & $\mathrm{F}_{\mathrm{FA}, \mathrm{Ay} / \mathrm{FA}}(\mathrm{t})=\mathrm{k}_{\mathrm{OX}} \mathrm{FA}(\mathrm{t}) \exp \left\{\mathrm{Ve}_{\mathrm{FAox}}\left[\Delta \mathrm{C}_{\mathrm{FA}}(\mathrm{t})\right]\right\}$ & 6.7 \\
\hline & $\mathrm{F}_{\mathrm{Ay}, \mathrm{FA} / \mathrm{FA}}(\mathrm{t})=\mathrm{k}_{\mathrm{ox}} \mathrm{FA}(\mathrm{t}) \exp \left\{\mathrm{Ve}_{\mathrm{Gl}}\left[\Delta \mathrm{C}_{\mathrm{Gl}}(\mathrm{t})\right]\right\}$ & 6.8 \\
\hline \multicolumn{3}{|l|}{ Acetyl-coA (Ay), mol } \\
\hline
\end{tabular}

${ }^{1}$ Refer to Tables 1, 2, and 3 for explanation of the notation and parameter values. 
References

This article cites 53 articles, 31 of which you can access for free at: http://jas.fass.org/content/89/10/3170\#BIBL 